NBER WORKING PAPER SERIES

\title{
DOES FAMILY STRUCTURE AFFECT \\ CHILDREN'S EDUCATIONAL OUTCOMES?
}

\author{
Donna K. Ginther \\ Robert A. Pollak \\ Working Paper 9628 \\ http://www.nber.org/papers/w9628 \\ NATIONAL BUREAU OF ECONOMIC RESEARCH \\ 1050 Massachusetts Avenue \\ Cambridge, MA 02138 \\ April 2003
}

\begin{abstract}
We thank Anne Case, Irwin Garfinkel, and James Heckman, all of whom discussed our paper at the AEA meetings in Boston in January, 2000, for their helpful suggestions. We also thank Daniel Black, Paula England, Nancy Folbre, Sara McLanahan, Gary Sandefur, Robert Willis, Finis Welch, and Madeline Zavodny for helpful comments. We thank the Graduate School at Washington University for providing funding for this research, and Mark Dollard for excellent research assistance. Pollak thanks the John Simon Guggenheim Memorial Foundation and the John D. and Catherine T. MacArthur Foundation for financial support. Previous versions of this paper were presented at the American Economic Association Annual Meeting, the MacArthur Network on the Family, the Economy and the NICHD Family and Child Wellbeing Research Network conference, "Conflict and Cooperation in Families," the Federal Reserve System Applied Microeconomics conference, the European Society of Population Economics conference, the Society of Labor Economists Conference, the University of Chicago, the University of Oregon, Oregon State University, Texas A\&M University, Southern Methodist University, the University of Kentucky, the University of Kansas, and the Population Association of America Annual Meeting. Any errors are the authors' responsibility. The views expressed herein are those of the authors and not necessarily those of the National Bureau of Economic Research.
\end{abstract}

C2003 by Donna K. Ginther and Robert A. Pollak. All rights reserved. Short sections of text not to exceed two paragraphs, may be quoted without explicit permission provided that full credit including Cnotice, is given to the source. 
Does Family Structure Affect Children's Educational Outcomes?

Donna K. Ginther and Robert A. Pollak

NBER Working Paper No. 9628

April 2003

JEL No. J1

\section{$\underline{\text { ABSTRACT }}$}

This paper makes two contributions. First, it adds to the growing literature describing correlations between children's educational outcomes and family structure. Although popular discussions focus on the distinction between two-parent families and single-parent families, McLanahan and Sandefur [1994] show that outcomes for stepchildren are similar to outcomes for children in single-parent families. McLanahan and Sandefur describe their results as showing that the crucial distinction is between children who were reared by both biological parents and children who were not. This description is misleading.

This paper shows that educational outcomes for both types of children in blended families -stepchildren and their half-siblings who are the joint biological children of both parents -- are similar to each other and substantially worse than outcomes for children reared in traditional nuclear families. We conclude that, as a description of the data, the crucial distinction is between children reared in traditional nuclear families (i.e., families in which all children are the joint biological children of both parents) and children reared in other family structures (e.g., single-parent families or blended families).

The paper's second contribution is to clarify the question, "What is the effect of family structure on outcomes for children?" Interpreted literally, the question asks about the effect of one endogenous variable on another. We argue for reformulating the family structure question by specifying some explicit counterfactual, and express a preference for a policy-relevant counterfactual. As an example, we suggest considering the effect of reducing the "marriage penalty" in the earned-income tax credit (EITC) that makes the credit essentially unavailable to two-earner couples. The EITC marriage penalty counterfactual, like any policy-relevant counterfactual, focuses attention on outcomes for those children whose parent's behavior is affected by the incentives created by the policy change.

Robert A. Pollak

John M. Olin School of Business

Washington University

Campus Box 1133

1 Brookings Drive

St Louis, MO 63130-4899

and NBER

pollak@olin.wustl.edu
Donna K. Ginther

Department of Economics

University of Kansas

1300 Sunnyside Drive

Lawrence, KS 66045-7585

dginther@ku.edu 


\section{Introduction}

What is the effect of family structure on educational outcomes for children? Everyone knows that children from two biological parent families do better than children from single-parent families. Journalists and politicians often assume that correlation implies causation. Economists know better.

This paper makes two contributions. First, we add to the growing literature describing correlations between children's educational outcomes and family structure. Although popular discussions focus on the distinction between two-parent families and single-parent families, McLanahan and Sandefur [1994] show, and other researchers have confirmed, that outcomes for stepchildren are similar to outcomes for children in single-parent families. McLanahan and Sandefur describe their results as showing that the crucial distinction is between children who were reared by both biological parents and children who were not. This description is misleading.

We show that, as a description of the data, the crucial distinction is between children who grow up in what the Census Bureau calls "traditional nuclear families" (i.e., families in which all children are the joint biological children of both parents) and children who grow up in other family structures (i.e., single-parent families; blended families). We show that outcomes for both types of children in blended families -- stepchildren and their half-siblings who are the joint biological children of both parents -- are similar to each other and substantially worse than outcomes for children reared in traditional nuclear families. Our blended family result adds to the stock of "stylized facts" -- simple empirical regularities looking for explanations. Our results also illustrate the importance of classification schemes.

Classification schemes often determine what we see. Nearly all previous research on family structure has viewed the world through a "child-based" classification scheme, classifying a child's family as a "stepfamily" or a "two-biological-parent family" on the basis of the child's relationship to the parents. With a child-based classification, the same blended family is a stepfamily for one child and a 
two biological parent family for another. Instead of a child-based classification of family structure, we use one that is "family-based." With a family-based classification, stepchildren and joint biological children who live together are said to belong to "blended families." Using a child-based classification, previous researchers focused on differences between children reared with a stepparent and children reared by both biological parents, a category that is dominated by children reared in traditional nuclear families but which also includes the joint biological children in blended families. Using a family-based scheme, we distinguish between children reared in traditional nuclear families and the joint biological children in blended families. We investigate whether outcomes for the joint biological children in blended families differ significantly or substantially from outcomes for children in traditional nuclear families, outcomes for stepchildren, or outcomes for children in single parent families.

The family structure literature has revealed more complicated patterns in the data than our previous paragraphs suggest. One strand in the literature moves from simple stylized facts -- differences in mean outcomes for children reared in various family structures -- to "descriptive regressions" that control for the effects of other variables such as mother's education and family income. We find that controlling for additional variables substantially reduces the correlation between children's educational outcomes and living in a single-parent family, and that often the effect of living in a single-parent family is no longer statistically significant.

Those who favor policies that promote marriage often cite stylized facts - simple correlations between family structure and children's outcomes -- while those skeptical of such policies respond by citing descriptive regressions that control for variables such as mother's education and family income. Both sides brandish descriptive regressions that support their positions, but the regressions used in the political debate are only summaries of correlations among endogenous variables. Honest policy debates rest on beliefs about structural relationships, not on stylized facts or descriptive regressions. 
Our second contribution is to clarify the question, "What is the effect of family structure on outcomes for children?" In economics most questions have default counterfactuals that are not spelled out explicitly because they are generally understood. For example, the question, "What would be the effect of a ten-cent increase in the gasoline tax?" implicitly compares the increase with leaving the gasoline tax unchanged. Questions about the effect of family structure lack default counterfactuals. Interpreted literally, the family structure question asks about the effect of one endogenous variable on another. A major source of confusion in the family structure literature is that the question is ill-posed. We argue for reformulating the family structure question by specifying an explicit counterfactual.

Any explicit counterfactual will nail down the family structure question, but we find policyrelevant counterfactuals most interesting. For example, consider the effect of eliminating the "marriage penalty" in the earned-income tax credit (EITC), a penalty that makes the credit essentially unavailable to two-earner couples. Advocates of incentives to induce individuals to enter marriage and stay married often cite the fact that, on average, children from two-parent families have better outcomes than children from single-parent families. Their implicit claim is that strengthening the incentives to marry (e.g., removing the marriage penalty) would increase the proportion of children who grow up in two-parent families and that, as a result, children's educational outcomes would improve. Reformulating the question as an explicit counterfactual, we focus attention on the effects of removing the EITC marriage penalty on marital and nonmarital fertility, and on outcomes for the children whose parents' behavior is altered by the change in incentives. Legislators' eyes may glaze over at the mention of treatment effects, but the idea is crucial. Stylized facts about mean differences in outcomes for children reared in traditional nuclear families and single-parent families are not evidence that removing the marriage penalty would improve outcomes for children. 
Our paper proceeds as follows. In section 1 we summarize briefly the empirical literature on family structure and outcomes for children. In section 2 we discuss our data and our estimation procedures and in section 3 our empirical results. Section 4 discusses counterfactuals and section 5 is our conclusion.

\section{Conceptual Issues and a Review of the Literature}

What is the effect of family structure on children's educational outcomes? Social scientists have written extensively on the relationship between family structure and children's socio-economic outcomes, some making modest claims about correlations and others making less-modest claims about causation. When estimating the determinants of education, economists often control for family structure, along with exogenous variables such as race and gender. ${ }^{1}$ Few researchers would claim that family structure is exogenous, and it is difficult to rule out the possibility that some unobserved variables or processes influence both family structure and educational outcomes. The threshold difficulty of estimating the causal effect of family structure on children's educational attainment is the lack of a well-specified counterfactual.

Perhaps the most influential work on the correlation between family structure and children's outcomes is McLanahan and Sandefur [1994]. They find that children who grow up in single-parent or stepparent families have lower educational attainment than those who grow up with both biological parents. The estimated correlations depend on the control variables used in the regression. After controlling for mother's employment and occupation, Biblarz and Raftery [1999] find that children living with both biological parents or a single-mother have higher occupational status and educational

\footnotetext{
${ }^{1}$ Several economists, including Haveman and Wolfe [1994, 1995] and Manski, McLanahan, Sandefur, and Powers [1992], Eckstein and Wolpin [1999], and Heckman, Hee, and Rubinstein [1999] include measures of family structure in estimates of children's educational outcomes. These estimates, however, are not linked to structural models of family structure and investments in children.
} 
attainment than children living with a stepparent or children living with a single father. Wojtkiewicz [1993] and Boggess [1998] find a negative and significant correlation between living with a stepfather and children's educational attainment.

To interpret these correlations as evidence of the causal effect of family structure on children's outcomes, researchers need to assume that family structure is exogenous. This assumption is false if there are processes that jointly determine family structure and children's outcomes. Researchers attempting to control for the endogeneity of family structure have made various identifying assumptions. Manski, Sandefur, McLanahan, and Powers [1992] evaluate the impact of alternative parametric and identification assumptions on the estimated effect of family structure on high school graduation. They demonstrate that the estimated effect depends on the identification assumptions imposed. They conclude: "Any attempt to determine the family structure effect more tightly must bring to bear prior information about the process generating family structure and children's outcomes. As long as social scientists are heterogeneous in their beliefs about this process, their estimates of family structure may vary" (p. 36).

Subsequent research that attempts to control for the endogeneity of family structure bears out this conclusion. Fixed effects estimates allow one to control for the endogeneity of family structure assuming there are unobserved family characteristics that are correlated with both child outcomes and family structure. Using fixed effects estimators, Ermisch and Francesconi [2001], Case, Lin and McLanahan [2001], and Evenhouse and Reilly [2001] find that family structure has a negative and significant effect on educational outcomes, while Gennetian [2001] finds no significant effect of family structure on children's cognitive assessment outcomes. Parental death, some researchers have argued, is a quasi-natural experiment that can be used to examine the effect of family structure on children's outcomes. Lang and Zagorsky [2001], Corak [2001], and Biblarz and Gottainer [2000] find that parent- 
absence due to death has less of an impact on children's outcomes than parent-absence due to divorce. Finally, using longitudinal data researchers have compared children's outcomes before and after divorce. Cherlin et al. [1991] find that elementary school children whose parents eventually divorce performed poorly in school prior to the change in family structure. Painter and Levine [1999], however, find no prior poor performance when they examine educational outcomes for teenagers.

The lack of a consensus about the effect of family structure on children's outcomes is striking. Research shows that living with a single-parent or a stepparent is correlated with poor outcomes for children. Biblarz and Raftery [1999] show that the correlations between family structure and children's outcomes diminish substantially as more family background variables are added to the specification. When researchers attempt to address the endogeneity of family structure, the estimated effect of family structure depends on the identification assumptions employed. The most consistent set of results are found when parental death is used as a quasi-natural experiment: the death of a parent appears to have a less negative effect on child outcomes than divorce. With the exception of Biblarz and Raftery [1999], few researchers have evaluated the robustness of the correlation between family structure and children's outcomes. In the next section we use three data sets to shed additional light on the correlation between family structure and educational attainment.

\section{Data and Estimation Strategy}

We use three data sets to investigate the association between family structure and children's educational outcomes: the National Longitudinal Survey of Youth (NLSY), the Panel Study of Income Dynamics (PSID), and the children of females from the National Longitudinal Survey of Youth (NLSYChild). The NLSY and PSID are used to examine the effect of family structure on four schooling outcomes for young adults: years of schooling, high school graduation, college attendance, college 
graduation. The NLSY-Child data are used to examine the effect of family structure on children's cognitive and behavioral outcomes: three Peabody Individual Achievement Tests (PIAT)--reading recognition, reading comprehension, and math--and the Behavior Problems index which measures a child's anti-social behavior.

The NLSY began in 1979 with a nationally representative sample of 12,686 young adults between the ages of 14 and 21. Almost half of the observations in the NLSY $(5,863)$ come from multiple sibling households. We work with an "NLSY sibling sample" which we define to include a subset of individuals who have siblings or stepsiblings in the NLSY. To be included in our sibling sample, individuals must have completed the 1988 Childhood Residence Calendar, have complete measures of schooling in at least one year between the 1990 and 1994 survey waves, and have at least one sibling meeting these criteria. We eliminate individuals who are adopted, or report zero years of schooling, or report more than one change in family structure in a given year of childhood.

The PSID began collecting data in 1968 on a nationally representative, longitudinal sample of 4,800 households. The PSID has followed individuals from their original families to new ones that form as a result of births, marriages, divorces, and children leaving home. Our sample consists of individuals born between 1960 and 1970 with educational outcomes observed between 1990 and 1993 and who have at least one sibling meeting these criteria. In 1985 the PSID collected retrospective data providing information on the pair-wise relationships of all individuals in a 1968 family. We use this information from the 1968-85 Relationship file to derive our measures of family structure. We eliminate individuals who are not included in the 1968-85 Relationship file, who do not have a biological parent in the PSID sample, who have no reported years of schooling, or who have no siblings meeting these criteria.

Beginning in 1986, the NLSY started collecting data biennially on all of the children born to the female NLSY respondents (the NLSY-Child data). The 1994 wave of the NLSY-Child sample contains 
information from 3,464 women with children Because children under the age of 15 make up the majority of this sample, we focus on cognitive and behavioral outcomes rather than schooling attainment. The assessment instruments we use in this study are three Peabody Individual Achievement Tests (PIAT) and the Behavior Problems index which measures a child's anti-social behavior. For all four assessments, we use the normalized percentile scores in our analysis. ${ }^{2}$ Our sample from the NLSYChild data is limited to children with siblings in the sample, ages 5-15 for whom we have data on age, the three PIAT assessments, and the Behavioral Problems index.

Given our focus on the effect of family structure on children's outcomes, the measurement of family structure requires explicit consideration. Previous studies have measured family structure as a dichotomous variable (e.g., does a child live with one or with both biological parents?) Dichotomous measures of family structure are unsatisfactory because family structure can change over the childhood (e.g., as the result of divorce or remarriage). Family structure measured at a child's particular age (age 14 in the NLSY) will not adequately reflect living arrangements that change during childhood. Wolfe, Haveman, Ginther, and An [1996] examine the effect of using these 'window' variable measures, conclude that one-year window variables serve as weak proxies for childhood circumstances and events, and can result in unreliable estimates. Children in multiple-sibling households may experience different family structures. For example, in blended families the youngest child may spend his or her entire childhood with both biological parents while the eldest child in the same family may be reared first by both biological parents, then by a single parent, and finally by one biological parent and a stepparent. Children living in these blended families share an environment that may have a similar impact on educational outcomes regardless of the child's biological relationship to the parents. Whether it does is, of course, an empirical question.

\footnotetext{
${ }^{2}$ Normalized percentile scores are derived on an age-specific basis. For the PIAT assessments, raw scores are normalized to a national distribution. For the Behavioral Problems Index, raw scores are normalized based on the survey distribution.
} 
In our analysis we use family-based measures of family structure created from retrospective data covering the entire childhood. ${ }^{3}$ In the PSID and NLSY, family structure is characterized as the proportion of childhood that a child lives with both biological parents and no half-siblings (traditional nuclear family), with a single biological parent (single-parent), with a biological parent who is married to a stepparent or with both biological parents and at least one half-sibling (blended families), and alternative (other) family structures. ${ }^{4}$ In the NLSY-Child survey, family structure is defined in each year of the survey data as living with a single mother, living with both biological parents and no half-siblings, or living in a blended family--defined as living with both biological parents and a half-sibling or living with a mother who is married to a stepfather. ${ }^{5}$ Even these definitions do not measure family structure over the entire childhood and may be subject to the 'window problem,' but because this reflects living arrangements over multiple survey years, they are presumably better than conventional, single-year measures of family structure.

We restrict our attention to outcomes for children from "stable blended families," which we define as those in which at least one sibling reports living with both biological parents for the entire childhood while at least one other sibling reports living with a stepparent. ${ }^{6}$ We impose this restriction to obtain a blended family sample in which at least one child in each family spends his or her entire

\footnotetext{
${ }^{3}$ Using the data collected by the 1988 NLSY Childhood Residence Calendar Supplement, we construct age-specific changes in family structure over an individual's entire childhood, from ages zero to 16. Using data collected in the 1968-85 PSID Family Relationship file, we construct age-specific changes in family structure over an individual's childhood from ages one to 16.

${ }^{4}$ We treat cohabiting biological parents as if they were married. Following the census definition, we say that a "blended" family is one "that must include at least one stepparent, stepsibling and/or half-sibling. A stepparent is the spouse of a child's biological parent but is not the child's biological parent. . Half-siblings share only one biological parent." [Census Bureau P70-38, p.B-1]. The census defines the "traditional nuclear family" as consisting of a married couple and their biological child(ren), with no others are present in the household. The proportion of childhood in a given family structure in the NLSY is measured as the number of years in that family structure divided by 17. In most cases an individual's childhood (ages 116) is not entirely observed between 1968 and 1985 in the PSID sample. Thus, we define family structure as the number of years a child between the ages of 1 and 16 is observed in the sample in a given family structure divided by the total number of years the child is ages 1-16 between 1968 and 1985 .

${ }_{6}^{5}$ Again we treat cohabiting biological parents as if they were married.

${ }^{6}$ Appendix A contains additional information on the identification of blended families in our sample and the definitions of the variables used in this study.
} 
childhood living with both biological parents. Our definition excludes "unstable" blended families that end in divorce. ${ }^{7}$

Table 1 reports the means and standard deviations of the variables used in the NLSY and PSID siblings sample along with the stable blended family subsamples. Almost 30 percent of the siblings in the NLSY and 48 percent of siblings in the PSID report ever living in a non-traditional family. ${ }^{8}$ Three percent of the siblings in the NLSY (154 individuals) and eight percent in the PSID (111 individuals) lived in stable blended families. ${ }^{9}$ Mean educational outcomes are lower in the stable blended family subsamples than for all siblings.

Table 2 reports the descriptive statistics for the NLSY-Child sample and our stable blended family subsample. There are 4,320 siblings in the sample, of whom 418 individuals live in stable blended families. Children in the NLSY-Child sample are repeatedly assessed, so we have over 10,000 child-year observations in this data set. Mean reading and math assessment scores are lower in stable blended families than for all of the siblings in the NLSY-Child sample; mean behavioral problem scores are higher.

We use these data to estimate the correlation between family structure and children's educational attainment. We make no attempt to control for the endogeneity of family structure because, as our literature review has demonstrated, the estimated results are highly sensitive to the modeling and identification assumptions employed. Instead, we focus on the robustness of the correlation between children's educational outcomes and family structure, sometimes controlling for other variables.

\footnotetext{
${ }^{7}$ It also excludes families in which none of the children are the biological children of both parents (e.g., the "Brady Bunch") because we want to compare schooling outcomes of step-children in blended families with the outcomes of their half-siblings who are the biological children of both parents .

${ }^{8}$ The percentage of siblings living in non-traditional families is greater in the PSID because of the oversampling of disadvantaged families.

${ }_{9}^{9}$ Because our blended families are defined as families that remain together for the entire childhood of at least one child, these percentages are not an estimate of the percentage of children in the population who spend some portion of their childhood in a family that includes a husband, a wife, at least one stepchild, and at least one biological child of the couple.
} 
We begin by estimating the correlation between family structure and educational outcomes using two models and the entire sample of siblings. We are motivated to take this approach by Biblarz and Raftery [1999] who show that the effect of family structure is sensitive to which control variables are included in the model. In addition to family structure, our first model includes the exogenous variables of gender and race. We exclude variables that measure inputs and behaviors chosen jointly with family structure, although several studies include such variables. ${ }^{10}$ In order to examine the sensitivity of family structure estimates to the inclusion of other control variables, we include variables such as sibship size (number of siblings), birth order, family income, religion, and parental schooling in the second specification.

In our second approach, we compare outcomes for half-siblings within the same stable blended family. We have defined our stable blended family samples in the NLSY and PSID to ensure that each family includes at least one child reared by both biological parents until age $16 .{ }^{11}$ If growing up with both biological parents has a substantial impact on children's educational outcomes, we would expect to find evidence of this in our stable blended family samples. That is, we would expect to find that children reared by both biological parents have better outcomes than their half-siblings who spent time in single-parent families and as stepchildren in stable blended families.

\section{Empirical Results}

\section{A. The Correlation Between Family Structure and Educational Outcomes}

We begin by estimating two cross-section models of the effect of family structure on schooling outcomes. Model (A) regresses schooling outcomes on variables for gender, race, an indicator for being

\footnotetext{
${ }^{10}$ See for example, Biblarz and Raftery [1999], Manski et al. [1992], and Lang and Zagorsky [2001].

${ }^{11}$ Stable blended families in the NLSY-Child are defined as at least one sibling living with both biological parents and a halfsibling in 1994.
} 
in the disadvantaged subsample, and family structure. Model (B) adds measures for number of siblings, birth order, family income, religion, and parental schooling to Model (A). Estimates using the NLSY are presented in Table 3, and those using the PSID are presented in Table 4. All standard errors are clustered by family and adjusted using the Huber-White method to account for the correlation between observations from the same family. The models use family-based measures of family structure; all models have measures for the proportion of childhood spent in a single-parent family, blended family, or other family structure with proportion spent in a traditional nuclear family being the omitted category. We can interpret the coefficient on proportion of childhood in a given family structure as the effect on schooling of spending an additional fraction of childhood in that family structure and correspondingly less in a traditional nuclear family.

Like previous research, our OLS and probit cross-section estimates of Models (A) in both data sets show that proportion spent with a single-parent family or blended family have negative and significant effects on schooling outcomes. As additional variables are included in Model (B), we observe results similar to those in Biblarz and Raftery [1999]. The estimated effect of growing up with a single-parent attenuates and is not statistically significant in seven of the eight models estimated in Tables 3 and 4. In estimates not reported here, we find that much of the attenuation in the effect of single-parent families on educational outcomes results from the inclusion of family income in Model B. Although the size of the coefficient on the blended family variable drops as we move from Model (A) to (B), the coefficient remains negative and statistically significant in five of the eight models. Our results suggest that the estimated effect of family structure is sensitive to the inclusion of other variables in the regression. ${ }^{12}$ After controlling for additional variables, blended families are more negatively correlated

\footnotetext{
${ }^{12}$ We have experimented with alternative specifications in Tables 3 and 4 and found our results to be robust. In appendix tables B.1 and B.2 we use dummy variables for family structure instead of proportion living in a particular family structure. The estimates presented in Tables 3 and 4 fit the data better than those using family structure dummies but tell the same story.
} 
with lower educational attainment than single-parent families.

We now turn to the effects of family structure on child assessment outcomes. Table 5 presents four sets of estimates for each of four child assessment outcomes (reading recognition, reading comprehension, math, and behavior problems). In the first OLS specification, Model (A), the normalized percentile assessment scores for each outcome is regressed on variables for age, gender, race, and family structure. Model (B) adds number of siblings, religion, mother's schooling, family income, and an indicator for low birth weight to Model (A). All standard errors are clustered by family and adjusted using the Huber-White method. Family structure is measured as an indicator variable for each year an individual is in the data set. The results for Model (A) indicate that living with a single parent or a blended family significantly decreases reading and math scores, and significantly increases behavior problems. The estimated effect of family structure on assessment outcomes decreases substantially in Model (B) when additional variables are included in the regression. The results in Table 5 indicate that living with a single-parent or a blended family is negative but no longer statistically significant in all but the reading recognition and behavior problems regressions.

\section{B. Blended Families Estimates}

We next consider educational outcomes in stable blended families. We begin with schooling outcomes. Because our stable blended-family sample is small in each data set, we combine the blended family subsamples from the PSID and NLSY for this analysis. Appendix Tables B.3 through B.6 contain separate analyses for the PSID and NLSY blended family subsamples. We begin with simple tests of differences in mean schooling outcomes. The top panel of Table 6 tests the null hypothesis of no difference in mean schooling outcomes between siblings in stable blended families and siblings from traditional nuclear families in the combined PSID-NLSY sample. For all four schooling outcomes we 
reject the null hypothesis of no difference in schooling outcomes. Mean schooling outcomes in the stable blended-family sample are substantially and significantly lower than those for children from traditional nuclear families.

Next, we compare the mean educational outcomes for joint biological children in stable blended families with the children in traditional nuclear families in the middle panel of Table 6 . In three of the four outcomes joint biological children from blended families have significantly lower educational attainment. Finally, we evaluate whether schooling outcomes within the stable blended-family sample differ for the stepchildren and the joint biological children. These results are presented in the bottom panel of Table 6. For all four schooling outcomes the children growing up with both biological parents in stable blended families do better than the step-children, but the differences in mean schooling outcomes are small relative to the difference between their schooling outcomes and those of children in traditional nuclear families. Furthermore, the difference between the stepchildren and the joint biological children in stable blended families is not statistically significant.

In Table 7, we estimate two models of schooling using the stable blended-family sample. ${ }^{13}$ Model (A) is a parsimonious model where family structure is measured as proportion of childhood in a non-intact family. We use this variable because it captures the differences between the step and joint biological children in the blended families. Model (B) includes additional family background characteristics. All standard errors are adjusted using the Huber-White method to account for the correlation between observations from the same family. In both models, the proportion of childhood

\footnotetext{
${ }^{13}$ Only three of the four schooling outcomes are presented in Table 6 because only 14 individuals in the blended-family sample graduated from college.
} 
spent in a non-intact family has a negative and statistically insignificant effect on educational attainment. $^{14}$

Using family-based measures of family structure, estimates of the effect of living with a single parent differ significantly depending on the variables included in the model. Regardless of the specification employed, however, the effect of living in a blended family remains negative and significant. When we examine the stable blended families sample, the differences in educational outcomes between the joint biological and stepchildren is small and both types of children in blended families do poorly when compared with children in traditional nuclear families. The tests of mean differences indicate that growing up in a stable blended family has a negative impact on schooling outcomes for both the stepchildren and the joint biological children. In the stable blended family regressions, the estimated effect of living without both biological parents is negative but no longer significant.

We now turn to the effect of family structure on the four child assessment outcomes. Table 8 reports results of tests of mean differences in the four assessment outcomes for children in the NLSYChild sample. The first panel in Table 8 shows statistically significant differences in mean outcomes between the children in the stable blended family sample and children from traditional nuclear families in the NLSY-Child sample. For all four outcomes, we reject the null hypothesis of no difference in mean scores across the two groups. The second panel of Table 8 compares the mean outcomes for joint biological children in stable blended families with children from traditional nuclear families. We again see large differences: the children in traditional nuclear families have substantially better outcomes.

\footnotetext{
${ }^{14}$ This result holds when the models are estimated separately for the PSID and NLSY. See Appendix Tables B.5 and B.6.
} 
The bottom panel of Table 8 reports mean outcomes within the stable blended family sample, comparing the stepchildren ("her children") with the joint biological children of both parents ("their children"). We find that stepchildren have lower mean scores on reading and math assessments and higher mean scores on behavioral problems. When we test the null hypothesis that there is no mean differences in outcomes between "her children" and "their children," we again fail to reject the null hypothesis: we find no significant difference in mean outcomes of the step children and the joint biological children in stable blended-families.

Finally, in Table 9 we present regression estimates of the effect of family structure on children's assessments using the NLSY-Child stable blended-family sample. Results for Models (A) and (B) are presented in the table for the four assessments. All standard errors are clustered by family and adjusted using the Huber-White method to account for the correlation between observations from the same family. We find that living in a single-parent or a blended family has a positive but insignificant effect on most of the PIAT assessments. Only one of the family structure variables is statistically significant in Table 9: living with a single parent has a positive and statistically significant effect on reading comprehension, even after controlling for family background characteristics.

Tables 8 and 9 indicate that stable blended family child assessment outcomes differ from the sample of all remaining siblings. Comparing the effect of family structure using the stable blendedfamily sample, we find that the estimated coefficients on the family structure variables often change signs and generally become statistically insignificant.

Our estimates using stable blended families show that outcomes for both types of children in blended families, stepchildren and their half-siblings who are the joint biological children of both parents, are substantially worse than for children reared in traditional nuclear families. Because these estimated correlations are merely the result of regressing one endogenous variable on another, however, 
they do not provide a basis for policy. In the next section we argue for reformulating the family structure question by specifying an explicit, policy-relevant counterfactual.

\section{Counterfactuals}

Any precisely specified counterfactual will clarify the family structure question, but economists are likely to favor policy-oriented counterfactuals, while marriage counselors and advice columnists are likely to favor personal counterfactuals. An example illustrates the distinction.

Suppose your cousin Carol tells you she is thinking of divorcing her husband and asks: "What would be the effect on my children?" To answer cousin Carol's question requires us to predict what would happen to her children under each decision. If she divorces, would she get custody of the children? Would she remarry? Would she increase her hours of work? Would she have additional children? We should certainly condition our answer to cousin Carol's question on all of our information about her and her children, including what we know about their personalities. We also need to predict outcomes for the children if she decides to remain in the marriage. If we have information about the quality of the marriage, we should clearly use it in predicting how the children would fare. Unlike the standard question -- "What is the effect of family structure on outcomes for children?" -- Cousin Carol's question is well-posed. It is not, however, policy relevant.

As an example of a policy-relevant counterfactual, we propose the removal of the marriage penalty that effectively prevents two-earner couples from using the earned-income tax credit (EITC). Other policyrelevant counterfactuals include removal of the marriage penalty from the federal income tax, voluntary or compulsory counseling for couples prior to marriage or for couples filing for divorce, and changes in the legal rules governing marriage, divorce, and child support. To estimate the effects of any policy change, we must specify it in detail. For example, in the case of the EITC marriage penalty, we must specify how its 
removal is financed. The easiest assumption is that the government finances it by increasing taxes on nonparents by enough to keep the removal of the marriage penalty revenue neutral.

Gruber [2000] investigates the effects of changes in state divorce laws on outcomes for children. The timing of the "divorce revolution" -- the transition from fault based divorce, to divorce by mutual consent, to unilateral divorce -- varied from state to state. Using this state variation, Gruber estimates the effect of unilateral divorce on outcomes for children. He finds that unilateral divorce has a negative and significant effect on children's educational attainment. Gruber reviews the family structure literature, which generally claims that divorce has adverse effects on outcomes for children. He criticizes that literature for failing to recognize and deal with the endogeneity of family structure. Although Gruber does not use the language of counterfactuals, unilateral divorce is clearly a policy relevant counterfactual.

The removal of the EITC marriage penalty encourages the formationand stability of married couple families. Its family structure effects, as opposed to its resource effects, are limited to children whose parents respond to the change in incentives. (A penalty on single parent families and cohabitating couples with children would encourage the formation and stability of married couple families without allowing them to experience resource effects.) Ignoring fertility effects, this means children who, without the policy change, would live in cohabiting or single parent families but who, with the policy change, would live in married couple families (i.e., traditional nuclear or blended families). Policy analysis begins with the effect of the policy change on each of the four family structures. ${ }^{15}$ Descriptive regressions suggest that outcomes for

\footnotetext{
15 Gruber [2000] investigates the effect of divorce law changes on child outcomes. The transition from bilateral to unilateral divorce has complicated effects on family structure because, as Gruber recognizes, divorce law changes affect not only bargaining within marriage but also entry into marriage.
} 
children in blended families are less favorable than outcomes for children in single parent families. If these correlations reflect causal relationships, then the removal of the marriage penalty will benefit some children and harm others.

As Heckman, Lochner, and Taber [1998a, 1998b] emphasize, the general equilibrium effect of policies that apply to the entire population cannot be inferred directly from their effects on individuals' behavior. Observational data and data from experimental programs that apply to a sample population provide a basis for estimating individuals' responses, but calculating general equilibrium effects requires more elaborate theory. In the case of the EITC, the general equilibrium effects operate through labor markets and marriage markets. If changes in incentives induce a substantial number of mothers and fathers increase their work hours, we would expect a decrease in the wages at the lower end of the skill distribution. If changes in incentives induce a substantial number of individuals who would not otherwise marry to enter marriage, we would expect the average "quality" of those marriages to be lower than the average quality of marriages before the change in incentives. The general equilibrium effects of removing the EITC marriage penalty may differ substantially from the partial equilibrium effects. In their study of college tuition subsidies, Heckman, Lochner and Taber find that the general equilibrium effects differ from the partial equilibrium effects by an order of magnitude.

Neither stylized facts nor descriptive regressions provide defensible estimates of even the partial equilibrium effects of eliminating the marriage penalty. As the marriage penalty counterfactual illustrates, designers of policy interventions need to know more about the determinants of outcomes for children than they can learn from stylized facts and descriptive regressions. 


\section{Conclusion}

In this paper we make two contributions. First, we augment the stock of stylized facts and descriptive regressions which summarize the correlations between family structure and children's educational outcomes. Second, we argue that stylized facts and descriptive regressions cannot support either scientific conclusions or policy analysis, and that explicit counterfactuals are required. An explicit counterfactual clarifies the question, "What is the effect of family structure on outcomes for children?"

Our contribution to the stock of stylized facts concerns blended families. It is well-known that, on average, children reared in traditional nuclear families have substantially better educational outcomes than stepchildren from stable blended families. We find that children reared in traditional nuclear families also have substantially better outcomes than the joint biological children from stable blended families. We also find that, within stable blended families the difference between the joint biological children and the stepchildren is neither substantial nor statistically significant.

Controlling not only for family structure but also for variables such as mothers' education and family income, descriptive regressions reveal a different pattern of family structure effects than the stylized facts which control only for family structure. With additional controls, the effect of family structure falls substantially and often loses statistical significance. In particular, the effect of living in a single-parent family is no longer statistically significant.

How can we understand these findings? Four explanations, separately or in combination, might account for at least some of them. First, family structure may well be a proxy for other variables that affect outcomes for children. To the extent that family structure is correlated with family resources devoted to children or time devoted to children, if descriptive regressions do not control for these variables, then family structure will pick up their effects. Because descriptive regressions do not correspond to either 
structural or reduced form relationships, there is no principled way to argue about which variables ought to be included and which excluded from a descriptive regression. ${ }^{16}$

The second explanation is stress. Although the Brady Bunch was preternaturally happy, the presence of stepchildren is often described as a source of stress. The sociologist Andrew Cherlin [1978] characterized remarriage as an "incomplete institution," arguing that roles in such families lack clear definition; for example, there is no consensus about when it is appropriate for a stepfather to discipline a stepchild. Most discussions of blended families focus on outcomes for stepchildren. Few researchers have discussed the joint biological children in blended families, although Gennetian [2001] is an important exception. ${ }^{17}$ The stresses and strains of blended families -- the presence of stepchildren, not necessarily the behavior of stepchildren -- might affect not only outcomes for the stepchildren but also outcomes for the joint biological children. Stress might explain why children in blended families have worse educational outcomes than children in other two-parent families.

The third explanation hinges on the allocation of time and other resources within blended families. If mothers allocate resources among children within blended families, and if all of the children are hers, as they usually are, then she may use her ability to allocate resources to "compensate" for any negative effects of family structure on stepchildren. This explanation highlights the fact that observed educational outcomes are not "pure" family structure effects, whatever that might mean, but also reflect the effects of any compensating or reinforcing family allocation decisions.

\footnotetext{
16 The discussion of the effect of family resources on outcomes for children provides an example. The papers in Duncan and Brooks-Gunn [1996] generally argue that increases in family resources have positive effects on child outcomes; Mayer [1997] argues that most of the observed correlation between family resources and child outcomes reflects unobserved heterogeneity; Blau [1999] provides a balanced summary of the discussion. The underlying difficulty is that the discussion of family resources effects, like the discussion of family structure effects, requires a well-specified counterfactual (e.g., an increase in cash welfare benefits; winning the lottery), but discussions of counterfactuals are conspicuously absent.

17 Evolutionary psychology suggests that stepchildren will be treated differently than biological children in blended families. Daly and Wilson [1999] and Popenoe [1994] draw on evolutionary psychology in their discussions of stepchildren. Booth and Dunn [1994], the edited volume in which Popenoe [1994] appears, contains several papers critical of Popenoe.
} 
The fourth explanation is heterogeneity. Observed heterogeneity draws our attention to the control variables, and the way in which investigators choose which of the available variables to control for. The descriptive regressions show that the correlations between family structure and outcomes for children fall substantially and often lack statistical significance when we control for variables such as mothers' education and family income. Unobserved heterogeneity draws our attention to differences in unobserved behaviors that may influence outcomes for children but also to differences in preferences and ability that influence the choice of family structure, education, and childbearing. Parents in blended families and single-parent families that result from divorce or nonmarital fertility may differ from parents in traditional nuclear families in unobserved as well as observed characteristics. Even if family structure has no "direct" or "causal" effect on outcomes for children, unobserved heterogeneity and selection could account for the association between outcomes for children and family structure summarized in the stylized facts and descriptive regressions.

Our second contribution is to argue the need to reformulate the family structure question using an explicit counterfactual. As an example of a reformulation of the question "What is the effect of family structure on outcomes for children?" we suggest a counterfactual based on eliminating the ETC marriage penalty. Our analysis also demonstrates, if another demonstration were needed, that what we see depends on the lens we look through -- the classification scheme we bring to the analysis. Classification schemes illuminate some relationships and obscure others. Furthermore, as Bowker and Star [1999] emphasize, classification schemes themselves often become visible only when alternatives appear. Using a family-based rather than a child-based classification of family structure, we see the children in blended families -- the step children and the joint biological children -- in a new light.

Any explicit counterfactual clarifies the family structure question, which, interpreted literally, asks about the effect of one endogenous variable on another. The elimination of the EITC marriage 
penalty exemplifies the type of counterfactual we have in mind. Its elimination would presumably provide incentives for individuals to enter marriage and remain married or, following divorce, to remarry. The marriage penalty counterfactual draws attention to the parents whom the changes in incentives would induce to marry or remain married, and to outcomes for their children.

Our results imply cautions for policy. Policies intended to improve outcomes for children often focus on family structure, which is easy to observe and, some believe, relatively easy to influence through tax and welfare policy, couple counseling, or legal rules governing marriage, divorce, and child support. If the stylized facts about the relationship between outcomes for children and family structure reflect the influences of other variables, then policies that affect family structure may have little or no effect on outcomes for children. Our blended family results and our descriptive regressions results call into question the causal interpretation of the stylized facts about the relationship between family structure and outcomes for children. 


\section{References}

Alm, James, Stacy Dickert-Conlin, and Leslie A. Whittington, “The Marriage Penalty," Journal of Economic Perspectives, Vol. 13, No. 3 (summer 1999), 193-204.

Antecol, Heather, Kelly Bedard, and Eric Helland, "Does Single Parenthood Increase the Probability of Teenage Promiscuity, Drug Use, and Crime? Evidence from Divorce Law Changes," mimeo, Claremont McKenna College, (2001).

Angrist, Joshua D. "Lifetime Earnings and the Vietnam Era Draft Lottery: Evidence From Social Security Administrative Records," American Economic Review, Vol. 80, No. 3, (June 1990), 313-336.

Behrman, Jere R., Mark R. Rosenzweig, and Paul Taubman, "Endowments and the Allocation of Schooling in the Family and the Marriage Market: The Twins Experiment," Journal of Political Economy, Vol. 102, No. 6, (December 1994), 1131-1174.

Biblarz, Timothy J., and Adrian E. Raftery, "Family Structure, Educational Attainment, and Socioeconomic Success: Rethinking the "Pathology of Matriarchy" American Journal of Sociology, Vol. 105, No. 2 (September 1999), 321-65.

Biblarz, Timothy J., and Greg Gottainer 'Family Structure and Children's Success: A Comparison of Widowed and Divorced Single-Mother Families," Journal of Marriage and Family, Vol. 62, (May 2000).

Blau, David M. "The Effect of Income on Child Development," Review of Economics and Statistics, Vol. 81, No. 2 (May 1999), 261-276.

Boggess, Scott, "Family Structure, Economic Status, and Educational Attainment," The Journal of Population Economics, Vol. 11, No. 2, (May 1998), 205-222.

Bowker, Geoffrey C. and Susan Leigh Star, Sorting Things Out: Classification and its Consequences, Cambridge: MIT Press, 1999.

Case, Anne, I-Fen Lin, and Sara McLanahan, "Household Resource Allocation in Stepfamilies: Darwin Reflects on the Plight of Cinderella," American Economic Review, Vol. 89, No. 2, (May 1999), 234238.

Case, Anne, I-Fen Lin, and Sara McLanahan, "Educational Attainment of Siblings in Stepfamilies," Evolution and Human Behavior. Vol. 22, No. 4, (September 2001), 269-289.

Cherlin, Andew, "Remarriage as an Incomplete Institution," American Journal of Sociology, Vol. 84, No. 3, (November 1978), 634-650.

Cherlin, Andrew J., Frank F. Furstenberg, P. Lindsay Chase-Lansdale, Kathleen E. Kiernan, et al., "Longitudinal Studies of Effects of Divorce on Children in Great Britain and the United States," Science, Vol. 252 No. 5011, (1991), 1386-89. 
Corak, Miles, "Death and Divorce: The Long-Term Consequences of Parental Loss on Adolescents," Journal of Labor Economics, Vol. 19, No. 3, (July 2001), 682-715.

Current Population Reports P23-181, Households, Families, and Children: A 30-Year Perspective, Washington, D.C: U.S. Government Printing Office (November 1992).

Daly, Martin and Margo Wilson, The Truth about Cinderella: A Darwinian View of Parental Love, New Haven: Yale University Press, 1999.

Department of Health and Human Services, Trends in the Well-Being of America's Children and Youth: 1996, Washington, D.C: U.S. Government Printing Office, 1996.

Duncan, Greg J. and Jeanne Brooks-Gunn, editors, Consequences of Growing Up Poor, New York: Russell Sage Foundation, 1996.

Eckstein, Zvi and Kenneth I. Wolpin, "Why Youths Drop Out of High School: The Impact of Preferences, Opportunities, and Abilities," Econometrica, Vol. 67, No. 6 (November 1999), 1295-1339.

Ermisch John F. and Marco Francesconi, "Family Structure and Children's Achievements," Journal of Population Economics, Vol. 14, No. 2 (2001), 249-270.

Evenhouse, Eirik, and Siobhan Reilly, "Selection Bias or Differential Treatment? Exploring Stepchildren's Poor Outcomes," mimeo, Mills College, (2001).

Evenhouse, Eirik, and Siobhan Reilly, "Divorce Laws and Divorce Rates: Evidence from Panel Data," mimeo, Mills College, (1997).

Gennetian, Lisa, "One or Two Parents? Half or Step Siblings? The Effect of Family Composition on Young Children.” MDRC, 2001.

Griliches, Zvi, "Sibling Models and Data in Economics: Beginning of a Survey," Journal of Political Economy, Vol. 87, No. 5 pt. 2. (October 1979), S37-S64.

Gruber, Jonathan, "Is Making Divorce Easier Bad for Children? The Long Run Implications of Unilateral Divorce." National Bureau of Economic Research Working Paper 7968, (2000).

Haveman, Robert and Barbara Wolfe, Succeeding Generations: On the Effects of Investments in Children, New York: Russell Sage Foundation, 1994.

Haveman, Robert, and Barbara Wolfe. "The Determinants of Children's Attainments: A Review of Methods and Findings," Journal of Economic Literature, Vol. XXXIII, No. 4, (December 1995) 18291878.

Heckman, James J., Lance Lochner, and Christopher Taber, "Evaluation of Education and Training Programs in a General Equilibrium Setting," March 1998. 
Heckman, James J., Lance Lochner, and Christopher Taber, "General Equilibrium Effects: A Study of Tuition Policy,” American Economic Review, Vol. 88, No. 2 (May 1998), 293-297.

Heckman, James J.,Jingjing Hee, and Yona Rubinstein, “The GED is a Mixed Signal,” December 1999.

Hrdy, Sarah Blaffer, Mother Nature: A History of Mothers, Infants, and Natural Selection: New York, Pantheon Books, 1999.

Lang, Kevin, and Jay L. Zagorsky, "Does Growing Up With a Parent Absent Really Hurt?" Journal of Human Resources, Vol. 36, No. 2, (Spring 2001), 253-273.

McLanahan, Sara and Gary Sandefur, Growing Up with a Single Parent: What Hurts, What Helps, Cambridge: Harvard University Press, 1994.

Manski, Charles, Gary Sandefur, Sara McLanahan, and Daniel Powers, "Alternative Estimates of the Effect of Family Structure During Adolescence on High School Graduation," Journal of the American Statistical Association, Vol. 87 No. 417, (March 1992), 25-37.

Mayer, Susan E., What Money Can't Buy: Family Income and Children's Life Chances, Cambridge: Harvard University Press, 1997.

Neal, Derek “The Economics of Family Structure," National Bureau of Economic Research Working Paper 8519, (2001).

NLSY79 User's Guide Handbook, Columbus, Ohio: Center for Human Resource Research, The Ohio State University, August 1997.

Painter, Gary and David I. Levine, "Family Structure and Youths' Outcomes: Which Correlations Are Causal?" Journal of Human Resources, Vol. 35, No. 3, (Summer 2000), 524-549.

Pollak, Robert A., "Conditional Demand Functions and Consumption Theory," Quarterly Journal of Economics, Vol. 83, No. 1, (February 1969), 60-78.

Popenoe, David, "The Evolution of Marriage and the Problem of Stepfamilies: A Biosocial Perspective," in Booth and Dunn [1994], pp. 3-27.

Willis, Robert J., “A Theory of Out-of-Wedlock Childbearing,” Journal of Political Economy, Vol. 107, No. 6, Part 2 (December 1999), S33-S64.

Wojtkiewicz, Roger A., "Simplicity and Complexity in the Effects of Parental Structure on High School Graduation,” Demography, Vol. 30, No. 4 (November 1993), 701-717.

Wojtkiewicz, Roger A., "The Effects of Single and Stepparent Families on College Entry: Who Gets Hurt the Most?," mimeo, Louisiana State University (1998). 
Wolfe, Barbara, Robert Haveman, Donna Ginther, and Chong Bum An, “The 'Window Problem' in Studies of Children's Attainments: A Methodological Exploration," Journal of the American Statistical Association, Vol. 91, No. 435 (September 1996), 970-982. 
Table 1

Descriptive Statistics NLSY and PSID Sibling Samples

\begin{tabular}{|c|c|c|c|c|}
\hline \multirow[b]{2}{*}{ Variable } & \multicolumn{2}{|c|}{ "NLSY } & \multicolumn{2}{|c|}{ PSID } \\
\hline & All Siblings & Half Sibs & All Siblings & Half Sibs \\
\hline \multirow[t]{2}{*}{ Years of Schooling } & 12.919 & 12.318 & 12.782 & 12.523 \\
\hline & $(2.273)$ & $(1.839)$ & $(1.871)$ & $(1.773)$ \\
\hline \multirow[t]{2}{*}{ High School Graduate $=1$} & 0.854 & 0.786 & 0.851 & 0.838 \\
\hline & $(0.353)$ & $(0.412)$ & $(0.356)$ & $(0.370)$ \\
\hline \multirow[t]{2}{*}{ College Attendance = 1} & 0.416 & 0.292 & 0.388 & 0.360 \\
\hline & $(0.493)$ & $(0.456)$ & $(0.488)$ & $(0.482)$ \\
\hline \multirow[t]{2}{*}{ College Graduate = 1} & 0.129 & 0.026 & 0.135 & 0.090 \\
\hline & $(0.335)$ & $(0.160)$ & $(0.342)$ & $(0.288)$ \\
\hline \multirow[t]{2}{*}{ Proportion Lived in Traditional Family } & 0.819 & 0.160 & 0.570 & 0.053 \\
\hline & $(0.325)$ & $(0.270)$ & $(0.479)$ & $(0.194)$ \\
\hline \multirow[t]{2}{*}{ Proportion Lived with Single Parent } & 0.114 & 0.129 & 0.238 & 0.081 \\
\hline & $(0.251)$ & $(0.236)$ & $(0.376)$ & $(0.209)$ \\
\hline \multirow[t]{2}{*}{ Proportion Lived in Blended Family } & 0.059 & 0.701 & 0.176 & 0.858 \\
\hline & $(0.194)$ & $(0.363)$ & $(0.335)$ & $(0.294)$ \\
\hline \multirow{2}{*}{$\begin{array}{l}\text { Proportion Lived in Other Family } \\
\text { Structure }\end{array}$} & 0.007 & 0.010 & 0.015 & 0.009 \\
\hline & $(0.053)$ & $(0.063)$ & $(0.087)$ & $(0.066)$ \\
\hline \multirow{2}{*}{$\begin{array}{l}\text { Lived in Traditional Family } \\
\text { Continuously }=1\end{array}$} & 0.698 & & 0.524 & \\
\hline & $(0.459)$ & & $(0.500)$ & \\
\hline \multirow[t]{2}{*}{ Lived in Single Parent Family $=1$} & 0.164 & 0.071 & 0.181 & 0.045 \\
\hline & $(0.370)$ & $(0.258)$ & $(0.385)$ & $(0.208)$ \\
\hline \multirow[t]{2}{*}{ Lived in Blended Family = 1} & 0.107 & 0.896 & 0.254 & 0.937 \\
\hline & $(0.309)$ & $(0.306)$ & $(0.435)$ & $(0.244)$ \\
\hline \multirow[t]{2}{*}{ Lived in Other Family Structure $=1$} & 0.031 & 0.032 & 0.041 & 0.018 \\
\hline & $(0.173)$ & $(0.178)$ & $(0.199)$ & $(0.134)$ \\
\hline \multirow[t]{2}{*}{ Female $=1$} & 0.480 & 0.461 & 0.507 & 0.550 \\
\hline & $(0.500)$ & $(0.500)$ & $(0.500)$ & $(0.500)$ \\
\hline \multirow[t]{2}{*}{ African American = 1} & 0.292 & 0.571 & 0.473 & 0.441 \\
\hline & $(0.455)$ & $(0.496)$ & $(0.499)$ & $(0.499)$ \\
\hline \multirow[t]{2}{*}{ Hispanic = 1} & 0.165 & 0.104 & 0.033 & \\
\hline & $(0.371)$ & $(0.306)$ & $(0.180)$ & \\
\hline \multirow[t]{2}{*}{ Birth Order } & 3.330 & 3.494 & 3.636 & 3.459 \\
\hline & (2.221) & $(2.124)$ & $(2.480)$ & $(2.396)$ \\
\hline \multirow[t]{2}{*}{ Number of Siblings } & 4.366 & 4.916 & 3.863 & 3.598 \\
\hline & $(2.653)$ & $(2.190)$ & $(1.655)$ & $(1.290)$ \\
\hline \multirow[t]{2}{*}{ Practiced Religion = 1} & 0.954 & 0.929 & 0.982 & 1.000 \\
\hline & $(0.210)$ & $(0.258)$ & $(0.134)$ & $(0.000)$ \\
\hline \multirow[t]{2}{*}{ Family Income } & 17793 & 15922 & 34314 & 31427 \\
\hline & $(13648)$ & $(12897)$ & $(22155)$ & $(12340)$ \\
\hline
\end{tabular}

Note: Standard Deviations in Parentheses. 
Table 1

Descriptive Statistics NLSY and PSID Sibling Samples (continued)

\begin{tabular}{|c|c|c|c|c|}
\hline \multirow{2}{*}{ Variable } & \multicolumn{2}{|c|}{ NLSY } & \multicolumn{2}{|c|}{ PSID } \\
\hline & All Siblings & Half Sibs & All Siblings & Half Sibs \\
\hline \multirow{2}{*}{ 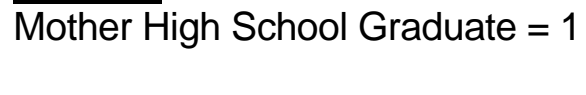 } & 0.358 & 0.286 & 0.356 & 0.396 \\
\hline & $(0.479)$ & $(0.453)$ & $(0.479)$ & $(0.491)$ \\
\hline \multirow[t]{2}{*}{ Mother Some College = 1} & 0.160 & 0.078 & 0.103 & \\
\hline & $(0.367)$ & $(0.269)$ & $(0.304)$ & \\
\hline \multirow[t]{2}{*}{ Mother's Schooling Missing = 1} & 0.056 & 0.065 & 0.024 & 0.018 \\
\hline & $(0.230)$ & $(0.247)$ & $(0.152)$ & $(0.134)$ \\
\hline \multirow[t]{2}{*}{ Father High School Graduate $=1$} & 0.277 & 0.227 & 0.211 & 0.216 \\
\hline & $(0.447)$ & $(0.420)$ & $(0.408)$ & $(0.414)$ \\
\hline \multirow[t]{2}{*}{ Father Some College = 1} & 0.208 & 0.097 & 0.150 & 0.072 \\
\hline & $(0.406)$ & $(0.297)$ & $(0.357)$ & $(0.260)$ \\
\hline \multirow[t]{2}{*}{ Father's Schooling Missing = 1} & 0.130 & 0.240 & 0.150 & \\
\hline & $(0.336)$ & $(0.429)$ & $(0.357)$ & \\
\hline Sample Size & 4764 & 154 & 1980 & 111 \\
\hline
\end{tabular}




\begin{tabular}{|c|c|c|c|c|}
\hline \multirow[b]{2}{*}{$\underline{\text { Variable }}$} & \multicolumn{2}{|c|}{ All Siblings } & \multicolumn{2}{|c|}{$\frac{\text { Stable Blended }}{\underline{\text { Families }}}$} \\
\hline & $\begin{array}{l}\text { Number } \\
\text { Of Obs. }\end{array}$ & Mean & $\begin{array}{l}\text { Number } \\
\text { of Obs. }\end{array}$ & Mean \\
\hline $\begin{array}{l}\text { PIAT- Reading Recognition Percentile } \\
\text { Score }\end{array}$ & 10803 & $\begin{array}{r}52.990 \\
(27.931)\end{array}$ & 1031 & $\begin{array}{r}49.890 \\
(27.522)\end{array}$ \\
\hline $\begin{array}{l}\text { PIAT-Reading Comprehension Percentile } \\
\text { Score }\end{array}$ & 8799 & $\begin{array}{r}50.839 \\
(27.745)\end{array}$ & 822 & $\begin{array}{r}47.658 \\
(27.506)\end{array}$ \\
\hline PIAT-Math Percentile Score & 10803 & $\begin{array}{r}45.141 \\
(26.335)\end{array}$ & 1031 & $\begin{array}{r}42.172 \\
(25.967)\end{array}$ \\
\hline $\begin{array}{l}\text { Behavioral Problems Index Percentile } \\
\text { Score }\end{array}$ & 10803 & $\begin{array}{r}64.347 \\
(26.564)\end{array}$ & 1031 & $\begin{array}{r}68.117 \\
(24.805)\end{array}$ \\
\hline Lived in Traditional Family & 10803 & $\begin{array}{r}0.475 \\
(0.499)\end{array}$ & 1031 & \\
\hline Lived with Single Mother & 10803 & $\begin{array}{r}0.377 \\
(0.485)\end{array}$ & 1031 & $\begin{array}{r}0.228 \\
(0.420)\end{array}$ \\
\hline Lived in Blended Family & 10803 & $\begin{array}{r}0.148 \\
(0.355)\end{array}$ & 1031 & $\begin{array}{r}0.772 \\
(0.420)\end{array}$ \\
\hline Age & 10803 & $\begin{array}{r}9.064 \\
(2.626)\end{array}$ & 1031 & $\begin{array}{r}9.129 \\
(2.681)\end{array}$ \\
\hline Real Family Income & 9165 & $\begin{array}{r}31907 \\
(60310)\end{array}$ & 877 & $\begin{array}{r}38391 \\
(78272)\end{array}$ \\
\hline Female $=1$ & 4320 & $\begin{array}{r}0.482 \\
(0.500)\end{array}$ & 418 & $\begin{array}{r}0.502 \\
(0.501)\end{array}$ \\
\hline African American $=1$ & 4320 & $\begin{array}{r}0.344 \\
(0.475)\end{array}$ & 418 & $\begin{array}{r}0.397 \\
(0.490)\end{array}$ \\
\hline Hispanic $=1$ & 4320 & $\begin{array}{r}0.215 \\
(0.411)\end{array}$ & 418 & $\begin{array}{r}0.208 \\
(0.406)\end{array}$ \\
\hline Number of Siblings & 4320 & $\begin{array}{r}2.139 \\
(1.169)\end{array}$ & 418 & $\begin{array}{r}2.656 \\
(1.396)\end{array}$ \\
\hline Practiced Religion = 1 & 4320 & $\begin{array}{r}0.406 \\
(0.491)\end{array}$ & 418 & $\begin{array}{r}0.385 \\
(0.487)\end{array}$ \\
\hline Mother High School Graduate $=1$ & 4320 & $\begin{array}{r}0.488 \\
(0.500)\end{array}$ & 418 & $\begin{array}{r}0.495 \\
(0.501)\end{array}$ \\
\hline Mother Some College = 1 & 4320 & $\begin{array}{r}0.272 \\
(0.445)\end{array}$ & 418 & $\begin{array}{r}0.251 \\
(0.434)\end{array}$ \\
\hline Low Birth Weight & 4320 & $\begin{array}{r}0.089 \\
(0.285) \\
\end{array}$ & 418 & $\begin{array}{r}0.105 \\
(0.307) \\
\end{array}$ \\
\hline
\end{tabular}

Note: Standard Deviations in Parentheses. 
Table 3

NLSY Sibling Estimates of the Effect of Family Structure on Schooling Outcomes

\begin{tabular}{|c|c|c|c|c|c|c|c|c|}
\hline & & & High S & hool & & & & \\
\hline & Years of $\mathrm{S}$ & nooling & Grad & ate & College At & endance & College G & aduate \\
\hline & OLS & $\underline{\text { OLS }}$ & Probit & Probit & Probit & Probit & Probit & Probit \\
\hline Variable & (A) & (B) & (A) & (B) & (A) & (B) & (A) & (B) \\
\hline Intercept & $13.269^{*}$ & $8.378^{*}$ & $1.219^{*}$ & $-1.874^{*}$ & $-0.085 \sim$ & $-2.499^{\star}$ & $-0.964^{*}$ & $-3.013^{*}$ \\
\hline & $(0.074)$ & $(0.562)$ & $(0.047)$ & $(0.412)$ & $(0.039)$ & $(0.380)$ & $(0.045)$ & $(0.482)$ \\
\hline Disadvantaged & $-0.914^{*}$ & $-0.333^{*}$ & $-0.485^{\star}$ & $-0.198 \sim$ & $-0.403^{*}$ & $-0.137 \sim$ & $-0.295^{\star}$ & -0.054 \\
\hline Oversample & $(0.116)$ & $(0.111)$ & $(0.079)$ & $(0.081)$ & (0.059) & $(0.069)$ & $(0.065)$ & $(0.088)$ \\
\hline Female & $0.417^{*}$ & $0.437^{*}$ & $0.244^{*}$ & $0.311^{*}$ & $0.223^{*}$ & $0.250^{*}$ & $0.165^{\star}$ & $0.208^{*}$ \\
\hline & $(0.066)$ & $(0.062)$ & $(0.047)$ & $(0.055)$ & $(0.039)$ & $(0.045)$ & $(0.049)$ & $(0.056)$ \\
\hline African-American & 0.101 & $0.672^{*}$ & $0.199 \sim$ & $0.468^{*}$ & 0.058 & $0.383^{*}$ & -0.092 & 0.148 \\
\hline & $(0.120)$ & $(0.112)$ & $(0.088)$ & $(0.092)$ & $(0.065)$ & $(0.075)$ & $(0.068)$ & $(0.086)$ \\
\hline Hispanic & -0.262 & $0.454^{*}$ & -0.078 & $0.197 \sim$ & -0.033 & $0.366^{*}$ & $-0.308^{*}$ & -0.041 \\
\hline & $(0.149)$ & $(0.141)$ & $(0.090)$ & $(0.097)$ & $(0.077)$ & $(0.090)$ & $(0.096)$ & $(0.116)$ \\
\hline Birth Order & & $0.050 \sim$ & & 0.029 & & 0.019 & & -0.006 \\
\hline & & $(0.024)$ & & $(0.018)$ & & $(0.017)$ & & $(0.024)$ \\
\hline Number of Siblings & & $-0.123^{*}$ & & $-0.067^{\star}$ & & $-0.064^{*}$ & & -0.028 \\
\hline & & $(0.022)$ & & $(0.016)$ & & $(0.016)$ & & $(0.021)$ \\
\hline Religion & & $0.494^{*}$ & & $0.447^{\star}$ & & 0.176 & & 0.050 \\
\hline & & $(0.188)$ & & $(0.116)$ & & $(0.115)$ & & $(0.151)$ \\
\hline Family Income 1979 & & $0.352^{*}$ & & $0.240^{*}$ & & $0.176^{\star}$ & & $0.162^{*}$ \\
\hline & & $(0.052)$ & & $(0.040)$ & & $(0.036)$ & & $(0.046)$ \\
\hline Mother High School & & $0.551^{*}$ & & $0.282^{*}$ & & $0.289^{\star}$ & & $0.191 \sim$ \\
\hline Graduate & & $(0.094)$ & & $(0.086)$ & & $(0.064)$ & & $(0.082)$ \\
\hline Mother Some College & & $1.266^{*}$ & & $0.405^{\star}$ & & $0.778^{*}$ & & $0.396^{*}$ \\
\hline & & $(0.131)$ & & $(0.129)$ & & $(0.087)$ & & $(0.099)$ \\
\hline Mother's Schooling & & -0.163 & & -0.174 & & -0.050 & & -0.067 \\
\hline Missing & & $(0.145)$ & & $(0.111)$ & & $(0.108)$ & & $(0.170)$ \\
\hline Father High School & & $0.397^{*}$ & & $0.411^{*}$ & & $0.198^{*}$ & & 0.122 \\
\hline Graduate & & $(0.096)$ & & $(0.083)$ & & $(0.066)$ & & $(0.081)$ \\
\hline Father Some College & & $1.545^{\star}$ & & $0.851^{*}$ & & $0.833^{*}$ & & $0.515^{*}$ \\
\hline & & $(0.124)$ & & $(0.143)$ & & $(0.080)$ & & $(0.090)$ \\
\hline Father's Schooling & & 0.080 & & 0.091 & & 0.021 & & -0.136 \\
\hline Missing & & $(0.114)$ & & $(0.086)$ & & $(0.083)$ & & $(0.125)$ \\
\hline Proportion with Single & $-0.674^{*}$ & -0.235 & $-0.417^{*}$ & $-0.253 \sim$ & $-0.356^{*}$ & -0.122 & $-0.374^{\star}$ & -0.194 \\
\hline Parent & $(0.159)$ & $(0.157)$ & $(0.106)$ & $(0.119)$ & $(0.092)$ & $(0.107)$ & $(0.122)$ & $(0.144)$ \\
\hline Proportion in Blended & $-0.894^{*}$ & $-0.517^{*}$ & $-0.259 \sim$ & -0.152 & $-0.562^{*}$ & $-0.322 \sim$ & $-0.965^{\star}$ & $-0.884^{*}$ \\
\hline Family & $(0.169)$ & $(0.161)$ & $(0.130)$ & $(0.140)$ & $(0.120)$ & $(0.135)$ & $(0.217)$ & $(0.247)$ \\
\hline $\begin{array}{l}\text { Proportion without } \\
\text { Parents }\end{array}$ & $\begin{array}{l}-1.459 \sim \\
(0.587)\end{array}$ & $\begin{array}{r}-0.641 \\
-(0.615)\end{array}$ & $\begin{array}{r}-0.678 \\
(0.369)\end{array}$ & $\begin{array}{r}-0.460 \\
\end{array}$ & $\begin{array}{r}-0.884 \\
(0.461)\end{array}$ & $\begin{array}{r}-0.494 \\
(0.515)\end{array}$ & $\begin{array}{r}-0.310 \\
(0.520)\end{array}$ & $\begin{array}{r}0.290 \\
\\
0589)\end{array}$ \\
\hline Parents & $(0.587)$ & $(0.615)$ & $(0.369)$ & $(0.451)$ & $(0.461)$ & $(0.515)$ & $(0.520)$ & $(0.589)$ \\
\hline Sample Size & 4674 & 3817 & 4674 & 3817 & 4674 & 3817 & 4674 & 3817 \\
\hline R-Squared & 0.074 & 0.288 & 0.047 & 0.162 & 0.036 & 0.162 & 0.044 & 0.115 \\
\hline
\end{tabular}

Notes: Robust standard errors clustered by family in parentheses. $p<.05=\sim$ and $p<.01={ }^{*}$. R-Squared for probit is a pseudo-R-squared. Sample size drops between models (A) and (B) because of missing family income data for some observations. 
Table 4

PSID Sibling Estimates of the Effect of Family Structure on Schooling Outcomes

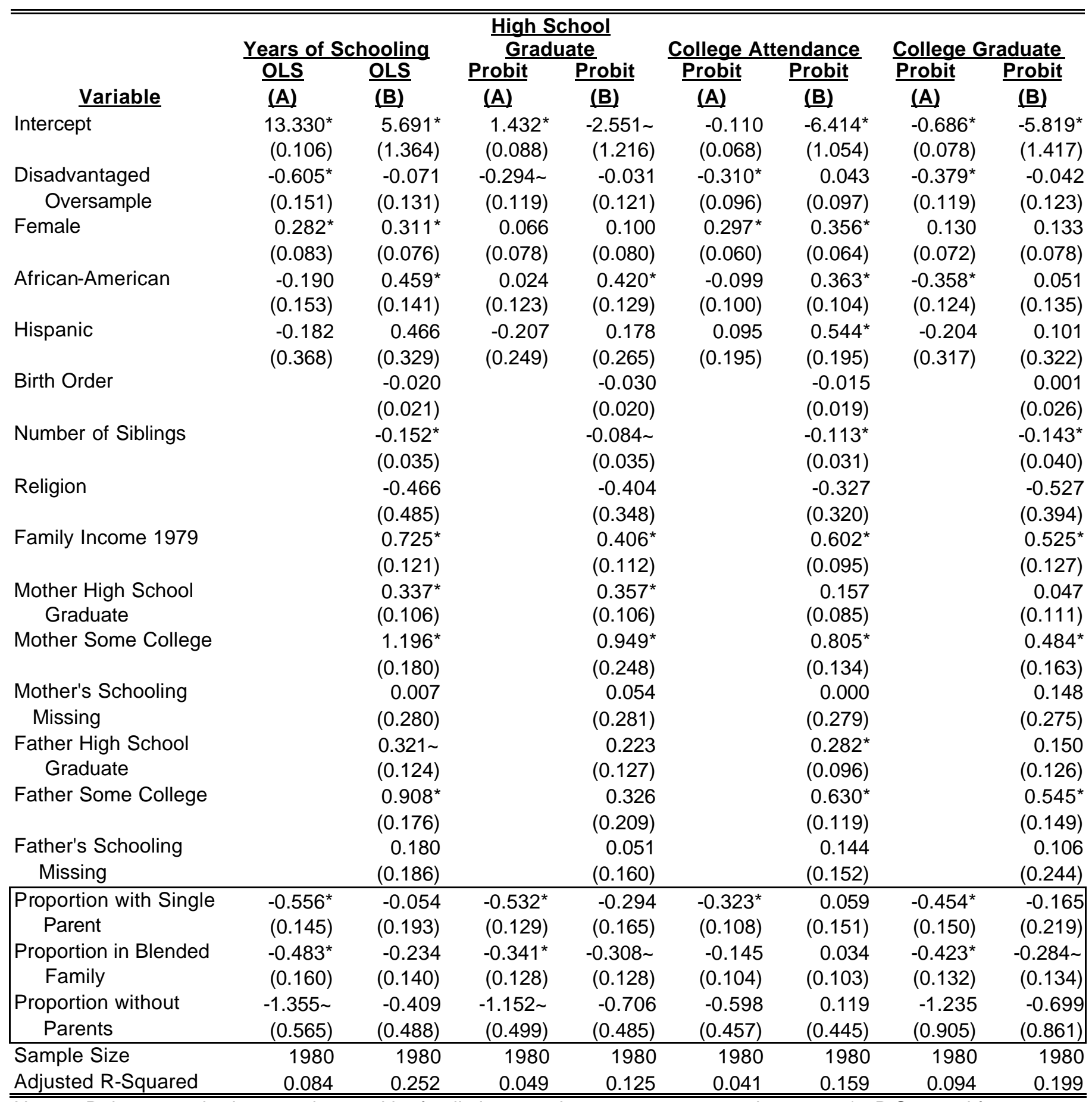

Notes: Robust standard errors clustered by family in parentheses. $p<.05=\sim$ and $p<.01={ }^{*}$. R-Squared for probit is a pseudo-R-squared. 
.Table 5

NLSY-Child Sibling Estimates of the Effect of Family Structure on Assessment Outcomes

\begin{tabular}{|c|c|c|c|c|c|c|c|c|}
\hline & \multicolumn{6}{|c|}{ Reading } & \multicolumn{2}{|c|}{ Behavioral } \\
\hline & \multicolumn{2}{|c|}{ Reading Recognition } & \multicolumn{2}{|c|}{ Comprehension } & \multicolumn{2}{|c|}{ Math Test Scores } & \multicolumn{2}{|c|}{ Problems Index } \\
\hline & OLS & OLS & OLS & OLS & OLS & OLS & OLS & OLS \\
\hline Variable & $(\mathrm{A})$ & (B) & $(\mathrm{A})$ & (B) & (A) & (B) & (A) & (B) \\
\hline \multirow[t]{2}{*}{ Intercept } & $65.551^{*}$ & $21.234^{*}$ & $90.458^{*}$ & $49.054^{*}$ & $56.728^{*}$ & $13.991 \sim$ & 57.020 * & $99.394^{*}$ \\
\hline & $(1.281)$ & $(5.817)$ & $(1.296)$ & $(6.753)$ & $(1.139)$ & (5.549) & $(1.317)$ & $(6.629)$ \\
\hline \multirow[t]{2}{*}{ Age } & $-0.798^{*}$ & $-0.801^{*}$ & $-3.430^{*}$ & $-3.244^{*}$ & $-0.244 \sim$ & -0.183 & $0.707^{*}$ & $0.677^{\prime}$ \\
\hline & $(0.124)$ & $(0.126)$ & $(0.122)$ & $(0.131)$ & $(0.106)$ & $(0.113)$ & $(0.113)$ & $(0.121)$ \\
\hline \multirow[t]{2}{*}{ Female } & $6.340^{*}$ & $6.342^{*}$ & $3.708^{*}$ & $3.551^{*}$ & 0.793 & 0.627 & $-5.085^{\star}$ & $-4.558^{*}$ \\
\hline & $(0.786)$ & $(0.771)$ & $(0.761)$ & $(0.732)$ & $(0.706)$ & $(0.703)$ & $(0.725)$ & $(0.753)$ \\
\hline \multirow[t]{2}{*}{ African-American } & $-8.026^{*}$ & $-6.288^{*}$ & $-9.098^{*}$ & $-7.256^{\star}$ & $-12.752^{*}$ & $-11.431^{*}$ & 0.747 & -0.655 \\
\hline & $(1.215)$ & (1.187) & (1.158) & $(1.142)$ & (1.083) & (1.090) & $(1.206)$ & (1.279) \\
\hline \multirow[t]{2}{*}{ Hispanic } & $-9.083^{*}$ & $-6.162^{*}$ & $-7.845^{\star}$ & $-4.916^{\star}$ & $-11.938^{*}$ & $-9.642^{*}$ & -0.303 & -1.824 \\
\hline & $(1.400)$ & $(1.284)$ & $(1.330)$ & $(1.221)$ & $(1.243)$ & $(1.171)$ & $(1.374)$ & $(1.441)$ \\
\hline \multirow[t]{2}{*}{ Number of Siblings } & & $-2.403^{*}$ & & $-2.198^{*}$ & & $-1.423^{*}$ & & 0.057 \\
\hline & & $(0.491)$ & & $(0.451)$ & & $(0.427)$ & & $(0.485)$ \\
\hline \multirow[t]{2}{*}{ Religion } & & $2.147 \sim$ & & $1.719 \sim$ & & 0.572 & & 0.226 \\
\hline & & $(0.840)$ & & $(0.818)$ & & $(0.762)$ & & $(0.853)$ \\
\hline Family Income & & $\begin{array}{l}3.776^{*} \\
(0.560)\end{array}$ & & $\begin{array}{l}3.288^{*} \\
(0.657)\end{array}$ & & $\begin{array}{l}3.611^{*} \\
(0.529)\end{array}$ & & $\begin{array}{l}-3.705^{\star} \\
(0.640)\end{array}$ \\
\hline Mother High School & & $7.033^{*}$ & & $7.670^{*}$ & & $6.132^{*}$ & & $-3.910^{*}$ \\
\hline Graduate & & $(1.294)$ & & $(1.287)$ & & $(1.103)$ & & $(1.445)$ \\
\hline \multirow[t]{2}{*}{ Mother Some College } & & $14.599^{*}$ & & $13.825^{*}$ & & $12.108^{*}$ & & $-4.392^{*}$ \\
\hline & & (1.483) & & $(1.480)$ & & $(1.338)$ & & (1.647) \\
\hline \multirow[t]{2}{*}{ Low Birth Weight } & & $-4.570^{*}$ & & $-4.371^{*}$ & & $-3.470^{*}$ & & 2.277 \\
\hline & & (1.604) & & (1.544) & & $(1.251)$ & & $(1.432)$ \\
\hline $\begin{array}{l}\text { Lives in Blended } \\
\text { Family }\end{array}$ & $\begin{array}{l}-4.360^{*} \\
(1.422)\end{array}$ & $\begin{array}{l}-3.099 \sim \\
(1.410)\end{array}$ & $\begin{array}{r}-2.872 \sim \\
(1.383)\end{array}$ & $\begin{array}{l}-1.970 \\
(1.343)\end{array}$ & $\begin{array}{l}-2.541 \sim \\
(1.251)\end{array}$ & $\begin{array}{l}-1.786 \\
(1.238)\end{array}$ & $\begin{array}{l}5.276^{*} \\
(1.270)\end{array}$ & $\begin{array}{r}4.012 \\
(1.356)\end{array}$ \\
\hline Lives with Single & $-7.772^{*}$ & -1.665 & $-7.028^{*}$ & -1.842 & $-5.917^{*}$ & -0.740 & $6.430^{*}$ & 2.138 \\
\hline Mother & $(1.087)$ & (1.138) & (1.058) & (1.178) & $(0.978)$ & $(1.026)$ & $(1.104)$ & (1.327) \\
\hline Sample Size & 10803 & 9109 & 8799 & 7424 & 10803 & 9109 & 10803 & 9109 \\
\hline R-Squared & 0.071 & 0.148 & 0.155 & 0.220 & 0.082 & 0.141 & 0.030 & 0.046 \\
\hline
\end{tabular}

Notes: Robust standard errors clustered by family in parentheses. $p<.05=\sim$ and $p<.01={ }^{*}$. R-Squared for probit is a pseudo-R-squared. Estimates use all observations without missing data. 


\section{Table 6}

Tests of Mean Differences in PSID and NLSY Sibling Sample

Test: Mean Outcome Half-Siblings in Stable Blended Families v. Siblings in Traditional Families

Mean

Mean

Half- $\quad$ Traditional

Outcome

Years of Schooling Siblings

Families

12.403

13.131

$\frac{\text { Test Statistic }}{6.256}$

P-value

High School Graduate

0.807

0.887

3.202

0.000

College Attendance

0.321

0.456

4.542

0.002

College Graduation

0.053

0.161

7.255

0.000

Sample Size

265

4301

Test: Mean Outcome in Traditional families v. Joint Biological in Stable Blended Family Sample

Mean

Mean

Outcome

Years of Schooling

High School Graduate

College Attendance

College Graduation

Sample Size

\section{Joint Biological}

12.508

0.855

0.339

0.040

124
Traditional Test Statistic

13.131

0.887

4.234

0.994

2.699

6.470

0.161

4301
P-value

0.000

0.322

0.008

0.000

Test: Mean Outcome Joint Biological v. Stepchild in Stable Blended Family Sample Mean Mean

Outcome

Years of Schooling High School Graduate College Attendance College Graduation Sample Size

\begin{tabular}{|c|c|c|c|}
\hline Biological & Stepchild & $\underline{\text { Test Statistic }}$ & $\underline{P \text {-value }}$ \\
\hline 12.312 & 12.508 & 0.891 & 0.374 \\
\hline 0.766 & 0.855 & 1.858 & 0.064 \\
\hline 0.305 & 0.339 & 0.584 & 0.560 \\
\hline 0.064 & 0.040 & -0.8633 & 0.389 \\
\hline 141 & 124 & & \\
\hline
\end{tabular}

Notes: Traditional defined as observed in the survey as always living with both biological parents. Stepchild defined as ever living with a stepparent. Numbers in Bold are statistically significant. 
Table 7

PSID and NLSY Blended Family Sample Estimates of the Effect of Family Structure on Educational Outcomes

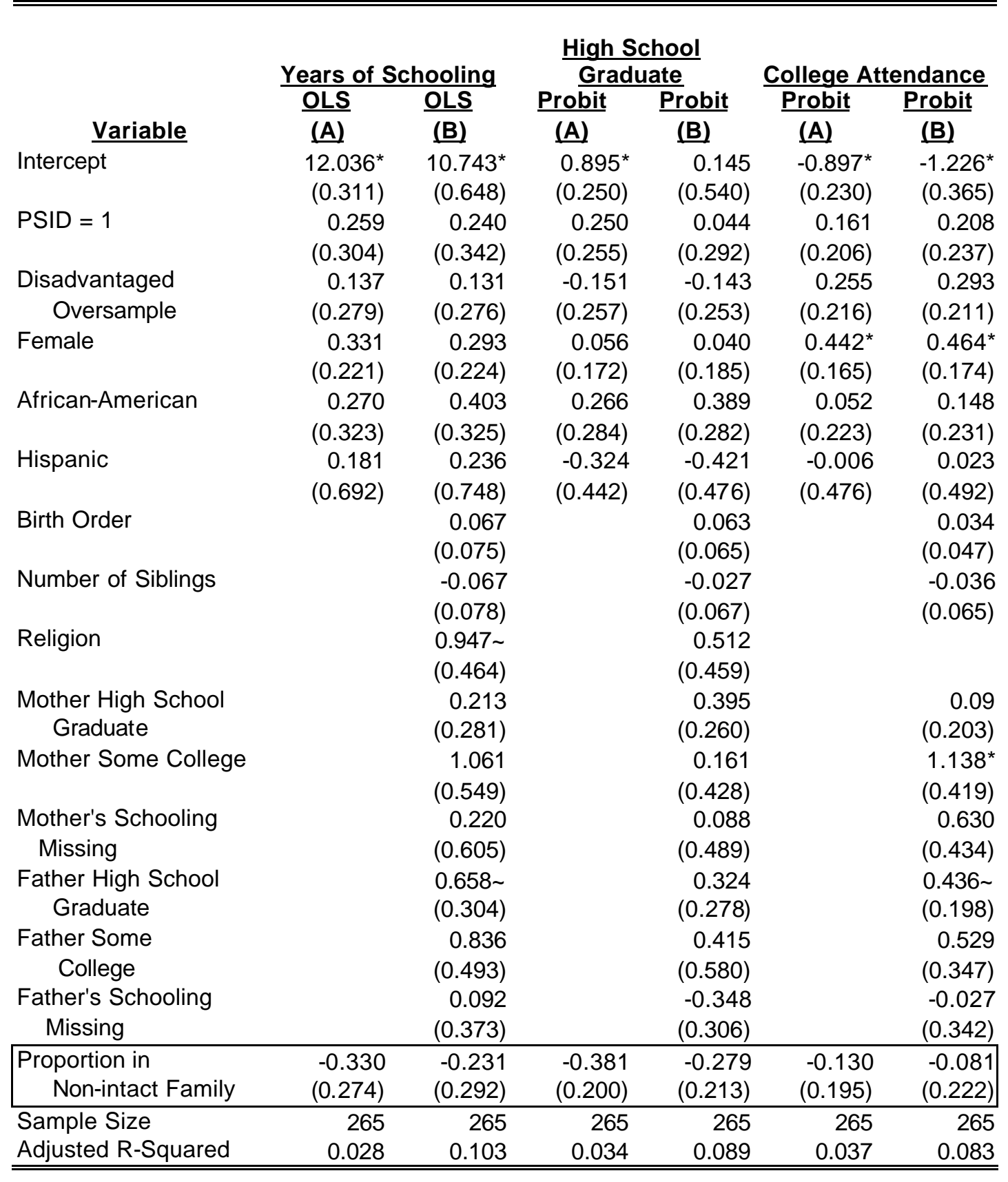

Notes: Robust standard errors clustered by family in parentheses. $p<.05=\sim$ and $p<.01={ }^{*}$. R-Squared for probit is a pseudo-R-squared 
Table 8

Tests of Mean Differences NLSY-Child Sibling Sample

Test: Mean Outcome Half-Siblings in Stable Blended Families

v. Siblings in Traditional Families

Mean

Mean

Half-

Outcome

PIAT-Reading Recognition

Siblings

PIAT-Reading Comprehension

49.369

Traditional

46.838

$\frac{\text { Families }}{57.896}$

Test

PIAT-Math

41.627

56.696

Statistic

6.364

6.945

P-value

Behavioral Problems Index

67.232

50.333

6.830

0.000

Sample Size

418

58.959

6.167

0.000

1861

Test: Mean Outcome in Traditional families v. Joint Biological in Stable Blended Family Sample

Mean

Outcome

Joint

Mean

$\frac{\text { Biological }}{49.615}$

49.645

Traditiona

42.025

65.559

199

57.896

56.696

50.333

58.958

Test

PIAT-Reading Recognition
PIAT-Reading Comprehension

1861

Statistic

P-value

0.000

Behavioral Problems Index

Sample Size

Bio

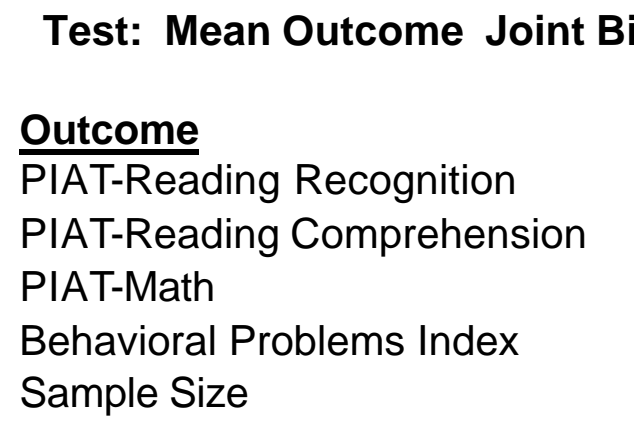

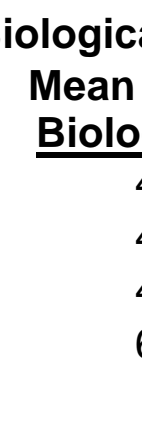

49.615

49.645

42.025

65.559

199
Mean

Stepchildre

49.145

44.994

41.264

68.753

219
4.485

0.000

0.001

$4.702 \quad 0.000$

$3.519 \quad 0.000$

Notes: Tests performed on average assessment scores. Traditional defined as observed in the survey as always living with both biological parents. Stepchild defined as ever living with a stepparent. Numbers in Bold are statistically significant. 
Table 9

NLSY-Child Blended Family Estimates of the Effect of Family Structure on Assessment Outcomes

\begin{tabular}{|c|c|c|c|c|c|c|c|c|}
\hline \multirow[b]{4}{*}{ Variable } & \multicolumn{6}{|c|}{ Reading } & \multicolumn{2}{|c|}{ Behavioral } \\
\hline & \multicolumn{2}{|c|}{ Reading Recognition } & \multicolumn{2}{|c|}{ Comprehension } & \multicolumn{2}{|c|}{ Math Test Scores } & \multicolumn{2}{|c|}{ Problems Index } \\
\hline & OLS & OLS & OLS & OLS & OLS & OLS & OLS & OLS \\
\hline & $(\mathrm{A})$ & (B) & $\underline{(A)}$ & (B) & $(\mathrm{A})$ & (B) & $(\mathrm{A})$ & $\underline{(B)}$ \\
\hline \multirow[t]{2}{*}{ Intercept } & $62.531^{*}$ & 22.869 & $87.854^{\star}$ & 26.162 & $53.486^{*}$ & 2.933 & $65.419^{*}$ & $104.838^{*}$ \\
\hline & (3.757) & $(18.321)$ & (3.855) & $(17.111)$ & $(3.240)$ & $(15.943)$ & (3.331) & $(17.025)$ \\
\hline \multirow[t]{2}{*}{ Age } & $-1.380^{*}$ & $-1.403^{*}$ & $-3.957^{*}$ & $-3.817^{*}$ & -0.417 & -0.406 & $0.985^{\star}$ & $0.786 \sim$ \\
\hline & $(0.485)$ & $(0.516)$ & $(0.417)$ & $(0.443)$ & $(0.323)$ & $(0.369)$ & $(0.306)$ & $(0.355)$ \\
\hline \multirow[t]{2}{*}{ Female } & $5.300 \sim$ & $6.140 \sim$ & 3.385 & 3.906 & 0.171 & -0.535 & $-6.395^{\star}$ & $-6.666^{*}$ \\
\hline & $(2.421)$ & (2.572) & (2.306) & $(2.330)$ & (2.058) & (2.085) & $(1.987)$ & (2.017) \\
\hline \multirow[t]{2}{*}{ African-American } & -6.574 & -6.245 & $-7.827 \sim$ & $-7.285 \sim$ & $-12.757^{*}$ & $-13.249^{*}$ & -4.441 & -4.006 \\
\hline & $(4.053)$ & $(3.980)$ & (3.753) & (3.569) & (3.403) & (3.327) & (3.052) & $(4.015)$ \\
\hline Hispanic & $\begin{array}{r}-9.375 \sim \\
(4.107)\end{array}$ & $\begin{array}{r}-6.098 \\
(3.923)\end{array}$ & $\begin{array}{l}-8.939 \sim \\
(3.592)\end{array}$ & $\begin{array}{r}-4.708 \\
(3.187)\end{array}$ & $\begin{array}{r}-11.253^{*} \\
(3.578)\end{array}$ & $\begin{array}{l}-8.563 \sim \\
(3.492)\end{array}$ & $\begin{array}{r}-4.992 \\
(3.576)\end{array}$ & $\begin{array}{r}-6.063 \\
(4.047)\end{array}$ \\
\hline \multirow[t]{2}{*}{ Number of Siblings } & & $-3.705^{\star}$ & & $-2.853 \sim$ & & -1.127 & & 0.368 \\
\hline & & (1.384) & & $(1.396)$ & & $(0.965)$ & & $(1.399)$ \\
\hline \multirow[t]{2}{*}{ Religion } & & 2.743 & & 1.332 & & 1.326 & & 3.604 \\
\hline & & (3.257) & & (3.079) & & $(2.788)$ & & $(2.708)$ \\
\hline Family Income & & $\begin{array}{l}4.297 \sim \\
(1.901)\end{array}$ & & $\begin{array}{r}6.135^{*} \\
(1.593)\end{array}$ & & $\begin{array}{r}4.682^{*} \\
(1.581)\end{array}$ & & $\begin{array}{l}-3.862 \sim \\
(1.701)\end{array}$ \\
\hline \multirow{2}{*}{$\begin{array}{l}\text { Mother High School } \\
\text { Graduate }\end{array}$} & & 1.300 & & 0.616 & & 4.057 & & -1.321 \\
\hline & & (3.943) & & (3.904) & & (3.195) & & (3.799) \\
\hline \multirow[t]{2}{*}{ Mother Some College } & & 9.881 & & 10.191 & & $12.074 \sim$ & & 0.728 \\
\hline & & (5.649) & & $(5.550)$ & & $(4.714)$ & & $(4.742)$ \\
\hline Low Birth Weight & & $\begin{array}{r}-3.623 \\
\end{array}$ & & $\begin{array}{r}-6.267 \\
\end{array}$ & & $\begin{array}{r}-4.484 \\
\end{array}$ & & $\begin{array}{r}1.549 \\
(3.742)\end{array}$ \\
\hline \multirow[t]{2}{*}{ Lives with Stepfather } & 4.406 & 2.514 & 4.533 & 3.610 & 1.438 & -0.209 & -1.914 & -2.097 \\
\hline & (3.254) & (3.413) & (3.191) & (3.374) & (2.557) & (2.528) & (2.161) & (2.448) \\
\hline Lives with Single & 1.581 & 8.032 & 1.277 & $8.380 \sim$ & -1.736 & 3.947 & 2.718 & -0.712 \\
\hline Mother & (3.767) & $(4.598)$ & (3.891) & $(4.206)$ & (2.992) & (3.432) & (2.789) & $(3.032)$ \\
\hline Sample Size & 1031 & 866 & 822 & 696 & 1031 & 866 & 1031 & 866 \\
\hline R-Squared & 0.045 & 0.136 & 0.146 & 0.243 & 0.060 & 0.128 & 0.036 & 0.050 \\
\hline
\end{tabular}

Notes: Robust standard errors clustered by family in parentheses. $p<.05=\sim$ and $p<.01={ }^{*}$. R-Squared for probit is a pseudo-R-squared. Estimates use all observations without missing data. 


\section{APPENDIX A: DATA CONSTRUCTION AND VARIABLE DEFINITIONS}

\section{Appendix A: Data construction and variable definitions}

\section{A. Identifying Blended Families}

In order to facilitate comparisons of outcomes for half-siblings in blended families we need to identify these households. Although the NLSY contains information on multiple sibling households, the data do not explicitly report whether a pair of siblings are half or full. The PSID does identify halfsiblings in the Family Relationship file. However, to facilitate comparisons across the data sets, we use the same identification approach for each. To identify half-siblings in the data, we compare measures of family structure in a household.

We use a similar approach to identify stable blended families in the NLSY-Child data. We identify half-siblings within a household using the following criteria: A) one sibling reports living with a father and the other reports not living with a father; or B) both siblings report not living with a father but report fathers living at different distances from the child; or C) one child reports the father is dead while the other does not. To make our NLSY-Child stable blended-family sample more nearly comparable to the NLSY stable blended-family sample, we impose the additional restriction that at least one child in the household reports having lived with both biological parents from birth until the time of the survey.

Table A.1 contains the definitions of the variables used in this analysis. 
Table A.1

Outcome and Family Structure Variable Definitions: PSID, NLSY, and NLSY-Child

\begin{tabular}{|c|c|}
\hline Outcome Variables: & Definitions: \\
\hline \multicolumn{2}{|l|}{ PSID and NLSY } \\
\hline \multirow[t]{2}{*}{ Years of Schooling } & $\begin{array}{l}\text { NLSY: Maximum years of schooling observed } \\
\text { 1985-1994 }\end{array}$ \\
\hline & $\begin{array}{l}\text { PSID: Maximum years of schooling observed } \\
\text { 1985-1997 }\end{array}$ \\
\hline High School Graduate $=1$ & $\begin{array}{l}\text { Indicator: Completed high school by } 1994 \text { in NLSY } \\
\text { by } 1997 \text { in PSID }\end{array}$ \\
\hline College Attendance $=1$ & $\begin{array}{l}\text { Indicator: Attended college by } 1994 \text { in NLSY } \\
\text { by } 1997 \text { in PSID }\end{array}$ \\
\hline College Graduate $=1$ & $\begin{array}{l}\text { Indicator: Completed college by } 1994 \text { in NLSY } \\
\text { by } 1997 \text { in PSID }\end{array}$ \\
\hline \multicolumn{2}{|r|}{ 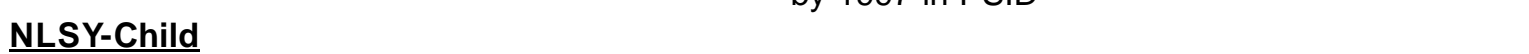 } \\
\hline $\begin{array}{l}\text { Peabody Individual Achievement Tests } \\
\text { Reading Recognition } \\
\text { Reading Comprehension } \\
\text { Math Percentile Scores }\end{array}$ & Nationally-normed percentile scores \\
\hline Behavioral Problems Index Percentile Score & $\begin{array}{l}\text { Survey-normed percentile score of behavioral } \\
\text { problems. }\end{array}$ \\
\hline NLSY and PSID Family Structure Variables: & Definitions: \\
\hline NLSY Proportion defined as: & $\begin{array}{l}\text { Years living in a given family structure(child ages } 0 \text { - } \\
\text { 16) divided by } 17\end{array}$ \\
\hline PSID Proportion defined as: & $\begin{array}{l}\text { Years observed between } 1968-85 \text { (child ages } 1-16 \text { ) } \\
\text { in a given family structure, divided by total years } \\
\text { observed between } 1968-85 \text { (child ages } 1-16 \text { ) }\end{array}$ \\
\hline Proportion Lived in Traditional Family & $\begin{array}{l}\text { Living with both biological parents and biological } \\
\text { siblings only }\end{array}$ \\
\hline Proportion Lived with Single Parent & $\begin{array}{l}\text { Living with either single mother or single father and } \\
\text { no stepparent }\end{array}$ \\
\hline Proportion Lived in a Blended Family & $\begin{array}{l}\text { Living with stepparent and biological parent who } \\
\text { are married; or living with both biological parents } \\
\text { and at least one half-sibling }\end{array}$ \\
\hline Proportion Lived in Other Family Structure & $\begin{array}{l}\text { Living without a biological parent and with other } \\
\text { relatives, foster care, etc. }\end{array}$ \\
\hline Lived in Traditional Family Continuously = 1 & $\begin{array}{l}\text { Indicator variable where proportion lived with both } \\
\text { biological parents }=1\end{array}$ \\
\hline Lived in Single Parent Family $=1$ & $\begin{array}{l}\text { Indicator variable where ever lived with a single } \\
\text { parent and never lived with a stepparent }\end{array}$ \\
\hline Lived in Blended Family = 1 & $\begin{array}{l}\text { Indicator variable where ever lived in a blended } \\
\text { family }\end{array}$ \\
\hline Lived in Other Family Structure $=1$ & $\begin{array}{l}\text { Indicator variable where ever lived without both } \\
\text { biological parents }\end{array}$ \\
\hline
\end{tabular}


Table A.1

Outcome and Family Structure Variable Definitions: PSID, NLSY, and NLSY-Child

\begin{tabular}{|c|c|}
\hline NLSY-Child Family Structure Variables: & Definitions \\
\hline \multicolumn{2}{|l|}{$\begin{array}{l}\text { Note: All Children in the NLSY-Child Sample } \\
\text { live with their biological mother. }\end{array}$} \\
\hline Lived in Traditional Family & Indicator for 1986, 1988, 1990, 1992, and 1994 \\
\hline Lived with Single Mother & Indicator for 1986, 1988, 1990, 1992, and 1994 \\
\hline Lived in Blended Family & Indicator for 1986, 1988, 1990, 1992, and 1994 \\
\hline \multicolumn{2}{|l|}{ Other Independent Variables: } \\
\hline Female $=1$ & Indicator: Female $=1$ \\
\hline African American $=1$ & Indicator: African-American $=1$ \\
\hline Hispanic $=1$ & Indicator: Hispanic=1 \\
\hline Birth Order & NLSY and PSID: Number of older siblings + 1 \\
\hline Number of Siblings & $\begin{array}{l}\text { NLSY: Average of number of siblings reported in } \\
1979 \text { and } 1993 \\
\text { PSID: Average number of siblings 1968-1985 } \\
\text { NLSY-Child: Total number of siblings } 1994\end{array}$ \\
\hline Practiced Religion = 1 & Indicator: child practiced religion $=1$ \\
\hline Family Income & $\begin{array}{l}\text { NLSY: Log of Family Income } 1979 \\
\text { PSID: Log of Average Family Income 1968-1985 } \\
\text { NLSY-Child: Log of Family Income in 1986, } 1988 \text {, } \\
\text { 1990, 1992, } 1994 \text { deflated by PCE deflator } \\
(1992=100)\end{array}$ \\
\hline Mother High School Graduate = 1 & $\begin{array}{l}\text { Indicator: Biological Mother is high school } \\
\text { graduate }\end{array}$ \\
\hline Mother Some College = 1 & $\begin{array}{l}\text { Indicator: Biological Mother has more than } 12 \\
\text { years of schooling }\end{array}$ \\
\hline Mother's Schooling Missing = 1 & Mother's education information missing \\
\hline Father High School Graduate $=1$ & Indicator: Biological Father is high school graduate \\
\hline Father Some College = 1 & $\begin{array}{l}\text { Indicator: Biological Father has more than } 12 \\
\text { years of schooling }\end{array}$ \\
\hline Father's Schooling Missing = 1 & Father's education information missing \\
\hline Age & NLSY-Child: Age in 1986, 1988, 1990, 1992, 1994 \\
\hline Low Birth Weight & Indicator for birth weight below 5.5 pounds \\
\hline
\end{tabular}




\section{APPENDIX B: SUPPLEMENTARY TABLES \\ Table B.1}

NLSY Sibling Estimates of the Effect of Family Structure on Schooling Outcomes Alternative Specification with Family Structure Indicator Variables

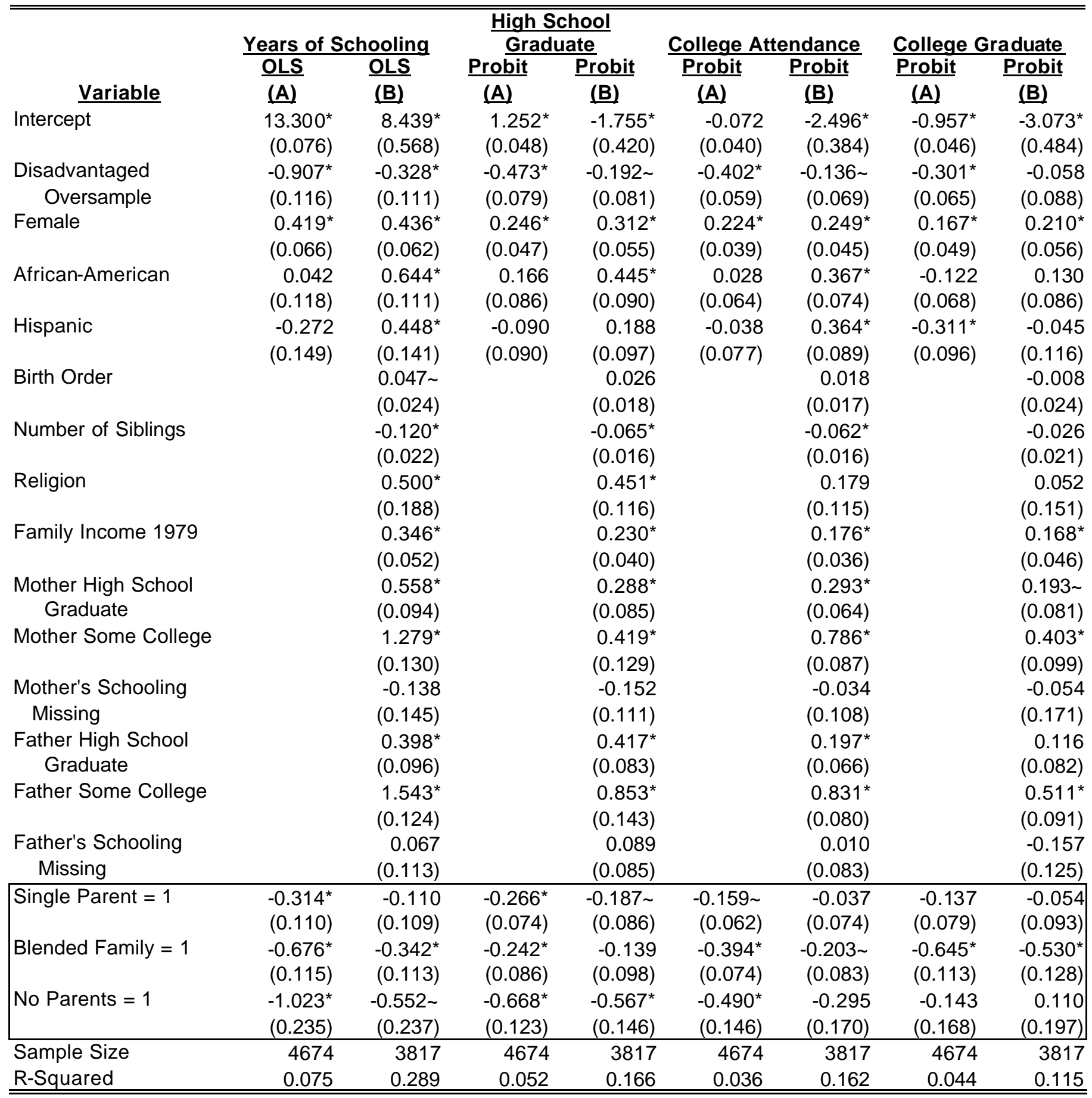

Notes: Robust standard errors clustered by family in parentheses. $\mathrm{p}<.05=\sim$ and $\mathrm{p}<.01={ }^{*}$. R-Squared for probit is a pseudo-R-squared. 
Table B.2

PSID Sibling Estimates of the Effect of Family Structure on Schooling Outcomes Alternative Specification with Family Structure Indicator Variables

\begin{tabular}{|c|c|c|c|c|c|c|c|c|}
\hline & & & High S & hool & & & & \\
\hline & Years of $\mathrm{S}$ & hooling & Gradt & ate & College At & endance & College G & aduate \\
\hline & OLS & $\underline{\text { OLS }}$ & Probit & Probit & Probit & Probit & Probit & Probit \\
\hline Variable & $\overline{(\mathrm{A})}$ & $\overline{(B)}$ & $\overline{(\mathrm{A})}$ & $\overline{(B)}$ & $\overline{(\mathrm{A})}$ & $\overline{(B)}$ & $\overline{(\mathrm{A})}$ & (B) \\
\hline Intercept & $\overrightarrow{13.358^{*}}$ & $6.619^{*}$ & $1.469^{*}$ & $\overrightarrow{-1.891}$ & -0.093 & $-5.845^{\star}$ & $-0.666^{*}$ & $-5.222^{*}$ \\
\hline & $(0.108)$ & $(1.340)$ & $(0.087)$ & (1.193) & $(0.070)$ & $(1.037)$ & $(0.079)$ & (1.409) \\
\hline Disadvantaged & $-0.605^{\star}$ & -0.053 & $-0.296 \sim$ & -0.014 & $-0.314^{*}$ & 0.057 & $-0.387^{*}$ & -0.041 \\
\hline Oversample & $(0.148)$ & $(0.129)$ & $(0.117)$ & $(0.119)$ & $(0.095)$ & $(0.097)$ & $(0.118)$ & $(0.122)$ \\
\hline Female & $0.282^{*}$ & $0.311^{*}$ & 0.069 & 0.104 & $0.299^{*}$ & $0.357^{*}$ & 0.131 & 0.138 \\
\hline & $(0.083)$ & $(0.075)$ & $(0.078)$ & $(0.080)$ & $(0.060)$ & $(0.064)$ & $(0.072)$ & $(0.078)$ \\
\hline African-American & -0.171 & $0.460^{*}$ & 0.027 & $0.419^{*}$ & -0.086 & $0.369^{\star}$ & $-0.352^{*}$ & 0.058 \\
\hline & $(0.151)$ & $(0.140)$ & $(0.123)$ & $(0.129)$ & $(0.099)$ & $(0.104)$ & $(0.122)$ & $(0.133)$ \\
\hline Hispanic & -0.217 & 0.444 & -0.247 & 0.143 & 0.076 & $0.533^{\star}$ & -0.224 & 0.093 \\
\hline & $(0.367)$ & $(0.328)$ & $(0.249)$ & $(0.266)$ & $(0.195)$ & $(0.195)$ & $(0.317)$ & $(0.318)$ \\
\hline Birth Order & & -0.016 & & -0.027 & & -0.012 & & 0.003 \\
\hline & & $(0.021)$ & & $(0.020)$ & & $(0.019)$ & & $(0.026)$ \\
\hline Number of Siblings & & $-0.163^{*}$ & & $-0.092^{*}$ & & $-0.122^{*}$ & & $-0.152^{*}$ \\
\hline & & $(0.034)$ & & $(0.034)$ & & $(0.030)$ & & $(0.040)$ \\
\hline Religion & & -0.551 & & -0.488 & & -0.368 & & -0.588 \\
\hline & & $(0.470)$ & & $(0.319)$ & & $(0.312)$ & & $(0.385)$ \\
\hline Family Income 1979 & & $0.649^{*}$ & & $0.355^{*}$ & & $0.555^{\star}$ & & $0.477^{*}$ \\
\hline & & $(0.119)$ & & $(0.110)$ & & $(0.094)$ & & $(0.127)$ \\
\hline Mother High School & & $0.322^{*}$ & & $0.353^{*}$ & & 0.143 & & 0.036 \\
\hline Graduate & & $(0.105)$ & & $(0.105)$ & & $(0.085)$ & & $(0.111)$ \\
\hline Mother Some College & & $1.217^{*}$ & & $0.967^{*}$ & & $0.814^{*}$ & & $0.500^{*}$ \\
\hline & & $(0.180)$ & & $(0.252)$ & & $(0.135)$ & & $(0.163)$ \\
\hline Mother's Schooling & & 0.057 & & 0.097 & & 0.036 & & 0.171 \\
\hline Missing & & $(0.270)$ & & $(0.278)$ & & $(0.281)$ & & $(0.274)$ \\
\hline Father High School & & $0.352^{*}$ & & $0.251 \sim$ & & $0.301^{*}$ & & 0.174 \\
\hline Graduate & & $(0.124)$ & & $(0.127)$ & & $(0.095)$ & & $(0.126)$ \\
\hline Father Some College & & $0.952^{*}$ & & 0.359 & & $0.660^{*}$ & & $0.578^{*}$ \\
\hline & & $(0.176)$ & & $(0.210)$ & & $(0.120)$ & & $(0.150)$ \\
\hline Father's Schooling & & $0.498^{*}$ & & 0.193 & & $0.401^{*}$ & & 0.323 \\
\hline Missing & & $(0.173)$ & & $(0.165)$ & & $(0.150)$ & & $(0.229)$ \\
\hline Single Parent $=1$ & $-0.673^{*}$ & $-0.511^{*}$ & $-0.588^{*}$ & $-0.529^{*}$ & $-0.406^{*}$ & $-0.311 \sim$ & $-0.539^{*}$ & $-0.492^{*}$ \\
\hline & $(0.144)$ & $(0.166)$ & $(0.132)$ & $(0.168)$ & $(0.109)$ & $(0.138)$ & $(0.152)$ & $(0.187)$ \\
\hline Blended Family = 1 & $-0.426^{*}$ & -0.186 & $-0.353^{*}$ & $-0.326^{*}$ & -0.160 & 0.017 & $-0.372^{*}$ & $-0.238 \sim$ \\
\hline & $(0.128)$ & $(0.114)$ & $(0.108)$ & $(0.109)$ & $(0.085)$ & $(0.087)$ & $(0.108)$ & $(0.112)$ \\
\hline No Parents $=1$ & $-1.063^{*}$ & $-0.577 \sim$ & $-0.918^{*}$ & $-0.720^{*}$ & $-0.495^{*}$ & -0.142 & $-0.794 \sim$ & -0.579 \\
\hline & $(0.255)$ & $(0.243)$ & $(0.215)$ & $(0.223)$ & $(0.178)$ & $(0.192)$ & $(0.324)$ & $(0.345)$ \\
\hline Sample Size & 1980 & 1980 & 1980 & 1980 & 1980 & 1980 & 1980 & 1980 \\
\hline Adjusted R-Squared & 0.091 & 0.256 & 0.058 & 0.133 & 0.045 & 0.162 & 0.098 & 0.203 \\
\hline
\end{tabular}

Notes: Robust standard errors clustered by family in parentheses. $p<.05=\sim$ and $p<.01={ }^{*}$. R-Squared for probit is a pseudo-R-squared. 
Table B.3

Tests of Mean Differences in NLSY Sibling Sample

\section{Test: Mean Outcome Half-Siblings in Stable Blended Families} v. Siblings in Traditional Families

Mean

Mean

Half- Traditional

Outcome

Years of Schooling Siblings 12.318 $\frac{\text { Families }}{13.125}$ $\frac{\text { Test Statistic }}{5.255}$

P-value

High School Graduate

0.786

0.879

2.779

0.000

College Attendance

0.292

0.456

4.327

0.006

College Graduation

0.026

0.150

8.645

0.000

Sample Size

154

3263

Test: Mean Outcome in Traditional families v.

Joint Biological in Stable Blended Family Sample

Outcome
Years of Schooling
High School Graduate
College Attendance
College Graduation
Sample Size

Mean Mean

Boint

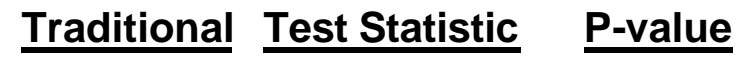

12.479

12.479

13.125

3.225

0.002

0.822

0.879

1.262

0.211

0.315

0.456

2.537

0.013

Sample Size

$\begin{array}{rr}0.041 & 0.150 \\ 73 & 3263\end{array}$

4.479

0.000

Test: Mean Outcome Joint Biological v. Stepchild in Stable Blended Family Sample

Outcome

Years of Schooling

High School Graduate

College Attendance

College Graduation

Sample Size
Mean

Joint

Biological

12.479

0.822

0.315

0.041

73
Mean

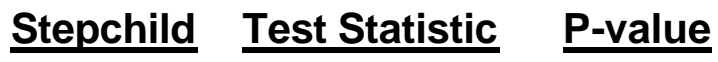

12.173

1.042

0.299

0.753

1.043

0.299

0.272

0.588

0.558

0.012

1.087

0.280

Notes: Traditional defined as observed in the survey as always living with both biological parents. Stepchild defined as ever living with a stepparent. Numbers in Bold are statistically significant. 


\begin{tabular}{|c|c|c|c|c|}
\hline \multirow[b]{2}{*}{ Outcome } & $\begin{array}{l}\text { Half-Sibling } \\
\text { gs in Tradit } \\
\text { Mean }\end{array}$ & $\begin{array}{l}\text { s in Stable B } \\
\text { ional Familie } \\
\text { Mean }\end{array}$ & $\begin{array}{l}\text { Iended Famili } \\
\text { s }\end{array}$ & \multirow[b]{2}{*}{ P-value } \\
\hline & $\frac{\text { Siblings }}{12.522}$ & $\frac{\frac{\text { Traditional }}{\text { Families }}}{13.150}$ & $\frac{\text { Test Statistic }}{3.513}$ & \\
\hline High School Graduate & 0.838 & 0.910 & 2.002 & 0.048 \\
\hline College Attendance & 0.360 & 0.456 & 1.973 & 0.051 \\
\hline College Graduation & 0.090 & 0.196 & 3.522 & 0.001 \\
\hline Sample Size & 111 & 1038 & & \\
\hline
\end{tabular}

Test: Mean Outcome in Traditional families v. Joint Biological in Stable Blended Family Sample

Outcome

Years of Schooling High School Graduate College Attendance College Graduation Sample Size

\section{Mean}

Joint Biological 12.549

0.902

0.373

0.039

51

\section{Mean}

Traditional Test Statistic

13.150

0.910

2.773

0.197

0.456

1.186

0.196

5.197

1038
P-value

0.007

0.845

0.241

0.000

Test: Mean Outcome Joint Biological v. Stepchild in Stable Blended Family Sample

Mean Mean

Outcome

Years of Schooling

High School Graduate

College Attendance

College Graduation

Sample Size
Joint Biological 12.549

0.902

0.373

0.039

60 Stepchild

$\underline{\text { Test Statistic }}$

P-value

12.500

0.148

0.883

0.783

1.741

0.085

0.350

0.244

0.808

0.133

$-1.807$

0.074

Notes: Traditional defined as observed in the survey as always living with both biological parents. Stepchild defined as ever living with a stepparent. Numbers in Bold are statistically significant. 
Table B.5

NLSY Blended Family Sample Estimates of the Effect of Family Structure on Educational Outcomes

\begin{tabular}{|c|c|c|c|c|c|c|}
\hline & & & High S & hool & & \\
\hline & Years of $S$ & hooling & Grad & ate & College At & endance \\
\hline & OLS & $\underline{\text { OLS }}$ & Probit & Probit & Probit & Probit \\
\hline Variable & (A) & (B) & (A) & (B) & (A) & (B) \\
\hline Intercept & $11.918^{*}$ & $10.704^{*}$ & $0.793^{*}$ & 0.074 & $-0.910^{*}$ & $-1.314^{*}$ \\
\hline & $(0.378)$ & $(0.758)$ & (0.294) & $(0.597)$ & $(0.283)$ & $(0.444)$ \\
\hline Disadvantaged & 0.119 & 0.095 & -0.023 & 0.038 & 0.130 & 0.122 \\
\hline Oversample & $(0.344)$ & (0.353) & $(0.351)$ & $(0.321)$ & $(0.320)$ & $(0.331)$ \\
\hline Female & 0.423 & 0.331 & 0.167 & 0.090 & $0.488 \sim$ & $0.561 \sim$ \\
\hline & $(0.285)$ & $(0.296)$ & $(0.206)$ & $(0.243)$ & $(0.221)$ & $(0.238)$ \\
\hline African-American & 0.593 & 0.681 & 0.262 & 0.450 & 0.247 & 0.379 \\
\hline & $(0.424)$ & $(0.372)$ & $(0.392)$ & $(0.387)$ & $(0.353)$ & $(0.374)$ \\
\hline Hispanic & 0.403 & 0.445 & -0.375 & -0.431 & 0.169 & 0.258 \\
\hline & $(0.717)$ & $(0.733)$ & $(0.489)$ & $(0.485)$ & $(0.519)$ & $(0.533)$ \\
\hline Birth Order & & 0.138 & & 0.180 & & 0.076 \\
\hline & & $(0.106)$ & & $(0.098)$ & & $(0.073)$ \\
\hline Number of Siblings & & $\begin{array}{r}-0.057 \\
(0.084)\end{array}$ & & $\begin{array}{r}-0.061 \\
(0.080)\end{array}$ & & $\begin{array}{r}-0.046 \\
(0.075)\end{array}$ \\
\hline Religion & & 0.738 & & 0.309 & & \\
\hline & & $(0.528)$ & & $(0.477)$ & & \\
\hline Mother High School & & -0.160 & & -0.071 & & 0.019 \\
\hline Graduate & & $(0.390)$ & & $(0.315)$ & & $(0.325)$ \\
\hline Mother Some College & & 0.941 & & 0.141 & & $1.230^{*}$ \\
\hline & & $(0.561)$ & & $(0.448)$ & & $(0.426)$ \\
\hline Mother's Schooling & & -0.089 & & -0.364 & & 0.625 \\
\hline Missing & & (0.792) & & $(0.637)$ & & $(0.563)$ \\
\hline Father High School & & 0.594 & & 0.366 & & 0.266 \\
\hline Graduate & & $(0.389)$ & & $(0.360)$ & & $(0.285)$ \\
\hline Father Some & & $1.348 \sim$ & & & & 0.803 \\
\hline College & & (0.563) & & & & $(0.416)$ \\
\hline Father's Schooling & & 0.069 & & -0.326 & & -0.026 \\
\hline Missing & & $(0.388)$ & & $(0.336)$ & & $(0.370)$ \\
\hline Proportion in & -0.665 & -0.602 & -0.406 & -0.350 & -0.325 & -0.377 \\
\hline Non-intact Family & $(0.364)$ & $(0.386)$ & $(0.231)$ & $(0.272)$ & $(0.261)$ & $(0.306)$ \\
\hline Sample Size & 154 & 154 & 154 & 139 & 154 & 143 \\
\hline Adjusted R-Squared & 0.06 & 0.165 & 0.037 & 0.111 & 0.045 & 0.123 \\
\hline
\end{tabular}

Notes: Robust standard errors clustered by family in parentheses. $\mathrm{p}<.05=\sim$ and $\mathrm{p}<.01={ }^{*}$. R-Squared for probit is a pseudo-R-squared. Some variables and observations are omitted from Model (B) because their inclusion predicts the outcome perfectly. 
Table B.6

PSID Blended Family Sample Estimates

of the Effect of Family Structure on Educational Outcomes

\begin{tabular}{|c|c|c|c|c|c|c|}
\hline & & & High S & hool & & \\
\hline & Years of $S$ & hooling & Grad & te & College At & endance \\
\hline & OLS & $\underline{\text { OLS }}$ & Probit & Probit & Probit & Probit \\
\hline Variable & $\overline{(\mathrm{A})}$ & $\overline{(B)}$ & $\overline{(\mathrm{A})}$ & $\overline{(B)}$ & $\overline{(\mathrm{A})}$ & $\overline{(B)}$ \\
\hline Intercept & $12.371^{*}$ & $12.278^{*}$ & $1.419^{*}$ & $1.213 \sim$ & $-0.809^{*}$ & -1.059 \\
\hline & $(0.391)$ & $(0.661)$ & $(0.389)$ & (0.592) & (0.304) & $(0.541)$ \\
\hline Disadvantaged & 0.024 & 0.203 & -0.396 & -0.258 & 0.332 & 0.470 \\
\hline Oversample & $(0.459)$ & $(0.409)$ & $(0.397)$ & $(0.403)$ & $(0.290)$ & $(0.263)$ \\
\hline Female & 0.296 & 0.362 & -0.142 & -0.051 & 0.443 & 0.456 \\
\hline & $(0.379)$ & $(0.389)$ & $(0.315)$ & (0.302) & $(0.277)$ & $(0.282)$ \\
\hline African-American & $\begin{array}{r}-0.015 \\
(0.491)\end{array}$ & $\begin{array}{r}0.216 \\
(0.549)\end{array}$ & $\begin{array}{r}0.293 \\
(0.400)\end{array}$ & $\begin{array}{r}0.259 \\
(0.428)\end{array}$ & $\begin{array}{r}-0.073 \\
(0.292)\end{array}$ & $\begin{array}{l}-0.009 \\
(0.321)\end{array}$ \\
\hline Hispanic & & & & & & \\
\hline Birth Order & & 0.066 & & 0.011 & & 0.037 \\
\hline & & $(0.114)$ & & $(0.085)$ & & $(0.065)$ \\
\hline Number of Siblings & & $\begin{array}{l}-0.242 \\
(0.199)\end{array}$ & & $\begin{array}{r}-0.066 \\
(0.148)\end{array}$ & & $\begin{array}{l}-0.081 \\
(0.125)\end{array}$ \\
\hline Religion & & & & & & \\
\hline $\begin{array}{l}\text { Mother High School } \\
\text { Graduate }\end{array}$ & & $\begin{array}{l}0.477 \sim \\
(0.378)\end{array}$ & & $\begin{array}{l}0.671 \sim \\
(0.342)\end{array}$ & & $\begin{array}{r}0.147 \\
(0.280)\end{array}$ \\
\hline Mother Some College & & & & & & \\
\hline Mother's Schooling & & 0.910 & & & & 0.610 \\
\hline Missing & & (0.689) & & & & $(0.441)$ \\
\hline Father High School & & 0.815 & & 0.269 & & $0.669^{*}$ \\
\hline Graduate & & $(0.430)$ & & $(0.414)$ & & $(0.239)$ \\
\hline Father Some & & 0.341 & & -0.354 & & 0.243 \\
\hline College & & (1.001) & & $(0.715)$ & & $(0.683)$ \\
\hline $\begin{array}{l}\text { Father's Schooling } \\
\text { Missing }\end{array}$ & & & & & & \\
\hline Proportion in & -0.041 & 0.117 & -0.405 & -0.353 & 0.032 & 0.122 \\
\hline Non-intact Family & $(0.419)$ & $(0.492)$ & $(0.333)$ & $(0.398)$ & $(0.301)$ & $(0.348)$ \\
\hline Sample Size & 111 & 111 & 111 & 109 & 111 & 111 \\
\hline Adjusted R-Squared & 0.007 & 0.089 & 0.034 & 0.092 & 0.027 & 0.068 \\
\hline
\end{tabular}

Notes: Robust standard errors clustered by family in parentheses. $p<.05=\sim$ and $p<.01={ }^{*}$. R-Squared for probit is a pseudo-R-squared. Some variables and observations are omitted from Model (B) because their inclusion predicts the outcome perfectly. 